\title{
Understanding processes at the origin of species flocks with a focus on the marine Antarctic fauna
}

\author{
Anne Chenuil ${ }^{*}$, Thomas Saucède ${ }^{2}$, Lenaïg G. Hemery ${ }^{3}$, Marc Eléaume ${ }^{4}$, \\ Jean-Pierre Féral ${ }^{1}$, Nadia Améziane ${ }^{4}$, Bruno David ${ }^{2,5}$, Guillaume Lecointre ${ }^{4}$ \\ and Charlotte Havermans ${ }^{6,7,8}$
}

\author{
${ }^{1}$ Institut Méditerranéen de Biodiversité et d'Ecologie marine et continentale (IMBE-UMR7263), Aix-Marseille Univ, Univ Avignon, CNRS, \\ IRD, Station Marine d'Endoume, Chemin de la Batterie des Lions, F-13007 Marseille, France \\ ${ }^{2}$ UMR6282 Biogéosciences, CNRS - Université de Bourgogne Franche-Comté, 6 boulevard Gabriel, F-21000 Dijon, France \\ ${ }^{3}$ DMPA, UMR 7208 BOREA/MNHN/CNRS/Paris VI/ Univ Caen, 57 rue Cuvier, 75231 Paris Cedex 05, France \\ ${ }^{4}$ UMR7205 Institut de Systématique, Evolution et Biodiversité, CNRS-MNHN-UPMC-EPHE, CP 24, Muséum national d'Histoire \\ naturelle, 57 rue Cuvier, 75005 Paris, France \\ ${ }^{5}$ Muséum national d'Histoire naturelle, 57 rue Cuvier, 75005 Paris, France \\ ${ }^{6}$ Marine Zoology, Bremen Marine Ecology (BreMarE), University of Bremen, PO Box 330440, 28334 Bremen, Germany \\ ${ }^{7}$ Alfred Wegener Institute Helmholtz Centre for Polar and Marine Research, Am Handelshafen 12, D-27570 Bremerhaven, Germany \\ ${ }^{8}$ OD Natural Environment, Royal Belgian Institute of Natural Sciences, Rue Vautier 29, B-1000 Brussels, Belgium
}

\begin{abstract}
Species flocks (SFs) fascinate evolutionary biologists who wonder whether such striking diversification can be driven by normal evolutionary processes. Multiple definitions of SFs have hindered the study of their origins. Previous studies identified a monophyletic taxon as a SF if it displays high speciosity in an area in which it is endemic (criterion 1), high ecological diversity among species (criterion 2), and if it dominates the habitat in terms of biomass (criterion 3); we used these criteria in our analyses. Our starting hypothesis is that normal evolutionary processes may provide a sufficient explanation for most SFs. We thus clearly separate each criterion and identify which biological (intrinsic) and environmental (extrinsic) traits are most favourable to their realization.

The first part focuses on evolutionary processes. We highlight that some popular putative causes of SFs, such as key innovations or ecological speciation, are neither necessary nor sufficient to fulfill some or all of the three criteria. Initial differentiation mechanisms are diverse and difficult to identify a posteriori because a primary differentiation of one type (genetic, ecological or geographical) often promotes other types of differentiation. Furthermore, the criteria are not independent: positive feedbacks between speciosity and ecological diversity among species are expected whatever the initial cause of differentiation, and ecological diversity should enhance habitat dominance at the clade level. We then identify intrinsic and extrinsic factors that favour each criterion. Low dispersal emerges as a convincing driver of speciosity. Except for a genomic architecture favouring ecological speciation, for which assessment is difficult, high effective population sizes are the single intrinsic factor that directly enhances speciosity, ecological diversity and habitat dominance. No extrinsic factor appeared to enhance all criteria simultaneously but a combination of factors (insularity, fragmentation and environmental stability) may favour the three criteria, although the effect is indirect for habitat dominance.

We then apply this analytical framework to Antarctic marine environments by analysing data from 18 speciose clades belonging to echinoderms (five unrelated clades), notothenioid fishes (five clades) and peracarid crustaceans (eight clades). Antarctic shelf environments and history appear favourable to endemicity and speciosity, but not to ecological specialization. Two main patterns are distinguished among taxa. ( $i$ In echinoderms, many brooding, species-rich and
\end{abstract}

* Address for correspondence (Tel: +33 491 041617; E-mail: anne.chenuil@imbe.fr) 
endemic clades are reported, but without remarkable ecological diversity or habitat dominance. In these taxa, loss of the larval stage is probably a consequence of past Antarctic environmental factors, and brooding is suggested to be responsible for enhanced allopatric speciation (via dispersal limitation). (ii) In notothenioids and peracarids, many clades fulfill all three SF criteria. This could result from unusual features in fish and crustaceans: chromosome instability and key innovations (antifreeze proteins) in notothenioids, ecological opportunity in peracarids, and a genomic architecture favouring ecological speciation in both groups. Therefore, the data do not support our starting point that normal evolutionary factors or processes drive SFs because in these two groups uncommon intrinsic features or ecological opportunity provide the best explanation. The utility of the three-criterion SF concept is therefore questioned and guidelines are given for future studies.

Key words: adaptive radiation, competition, diversification, ecological niche, endemicity, extinction, life-history trait, phylogeny.

\section{CONTENTS}

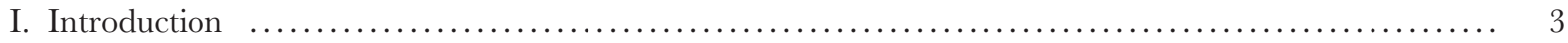

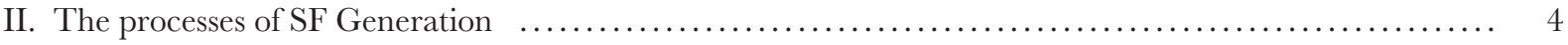

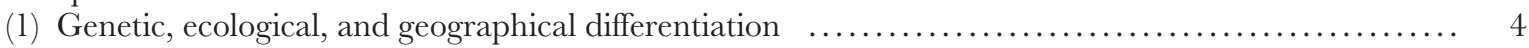

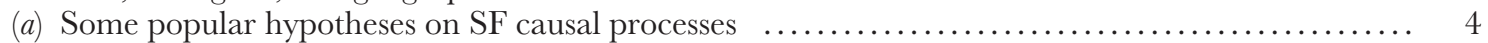

(b) Difficulty in identifying initial differentiation mechanisms $\ldots \ldots \ldots \ldots \ldots \ldots \ldots \ldots \ldots \ldots \ldots \ldots \ldots$

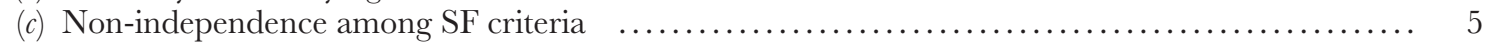

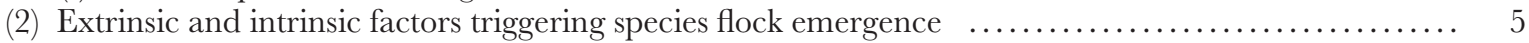

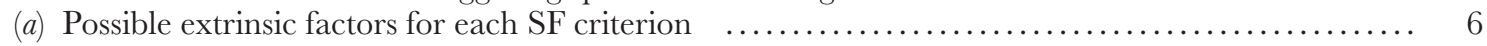

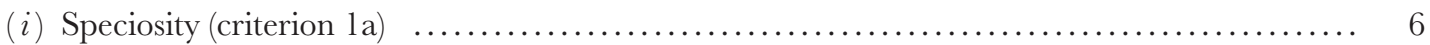

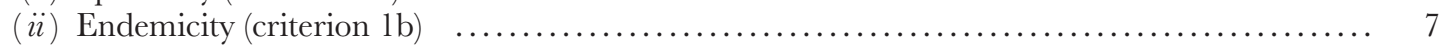

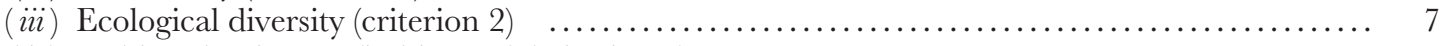

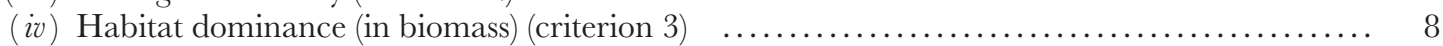

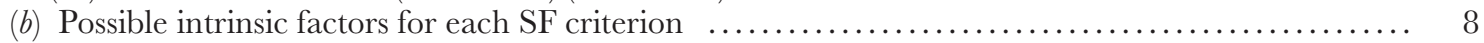

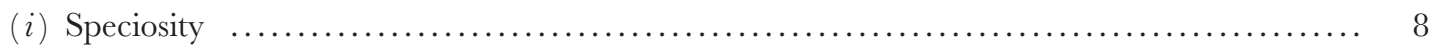

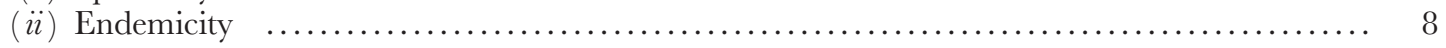

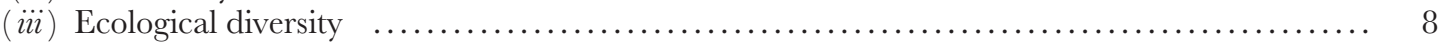

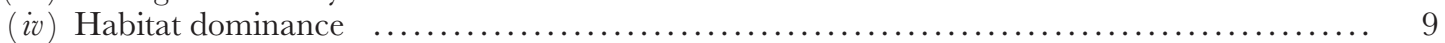

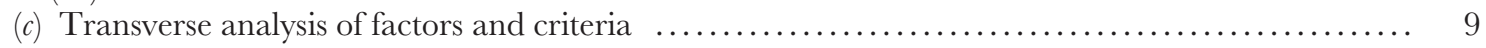

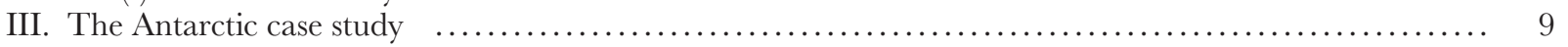

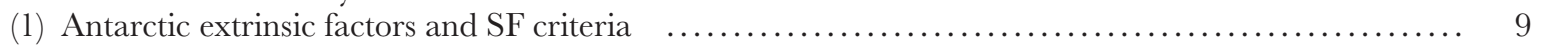

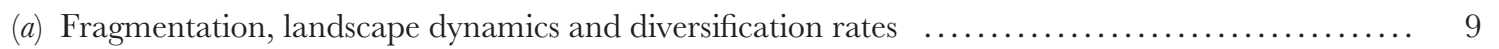

(b) Ancient isolation and a large area enhance speciosity and endemicity $\ldots \ldots \ldots \ldots \ldots \ldots \ldots \ldots$

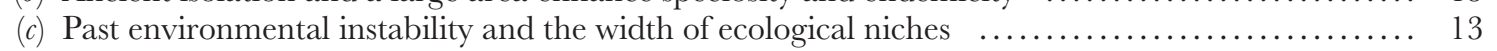

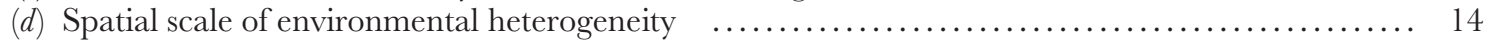

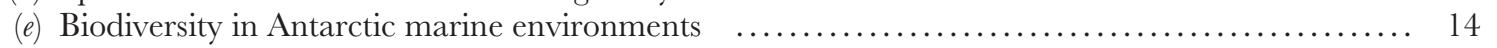

(f) Extreme physical factors, key adaptations and ecological opportunity $\ldots \ldots \ldots \ldots \ldots \ldots \ldots \ldots \ldots$

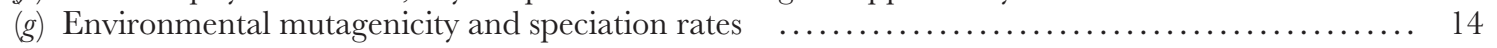

(h) Extrinsic factors shaped similar intrinsic features in various clades $\ldots \ldots \ldots \ldots \ldots \ldots \ldots \ldots \ldots \ldots$

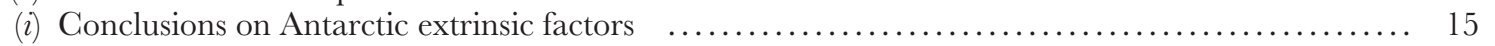

(2) Biological (intrinsic) traits of Antarctic marine clades and SF criteria $\ldots \ldots \ldots \ldots \ldots \ldots \ldots \ldots \ldots \ldots$

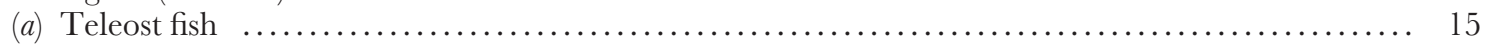

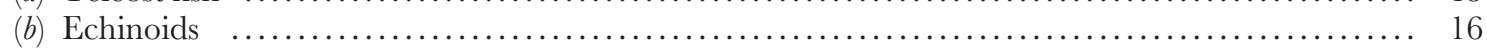

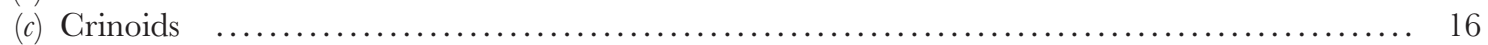

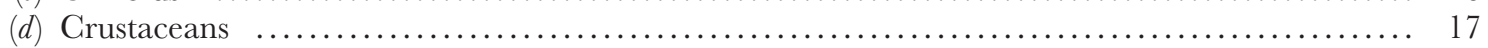

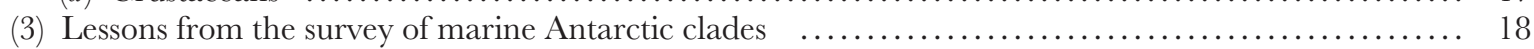

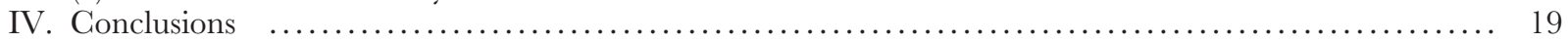

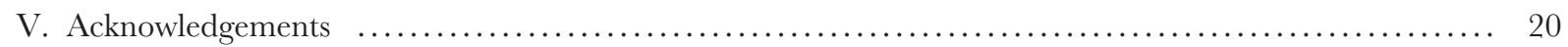

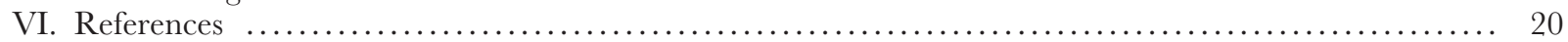

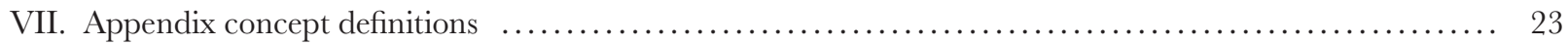




\section{INTRODUGTION}

Species flocks (SFs) are striking examples of diversifications circumscribed to a geographical area and have puzzled biologists for decades. Their origins have been debated, with a tendency to identify a single cause (e.g. sympatric speciation, key innovation) rather than to consider in detail the evolutionary processes involved. Two extreme points of view can be identified: one considering that a single but highly unusual process, biological or ecological factor is responsible for SFs, and the other considering that normal evolutionary processes, which may enhance one another, underlie the origins of SFs (including conditions in which the biological or ecological parameters take extreme values). The latter explanation has been neglected, particularly in the marine scientific community, despite providing a null model that should be rejected before invoking particularly unusual or ad hoc phenomena. There are several definitions of SFs available (e.g. Greenwood, 1984; Mayr, 1984; Ribbink, 1984) and a diversity of criteria allowing their detection (Eastman \& McCune, 2000; Lecointre et al., 2013). Some are heterogeneous, combining historical and contemporary criteria as well as patterns (related to speciosity and biogeography) and processes (related to diversification rates, ecology and speciation). The confusion with respect to evolutionary processes in the SF literature motivated us to undertake this study. Our aim is explicitly to separate the different processes that are necessary and sufficient to the realization of each SF identification criterion. This approach may reveal whether some biological traits or biogeographic regions are more likely to generate SFs. To make our analysis useful to all SF concepts we used a criterion-rich approach, including ecological criteria that are not considered in some SF definitions (e.g. Greenwood, 1984), and we examined these criteria independently. We focus on the evolutionary processes required to fulfill each of the criteria used to characterize SFs.

Lecointre et al. (2013) only considered monophyletic units (clades) as potential SFs. These authors identified five criteria that must be fulfilled for a SF to be present in a group of organisms: monophyly, endemicity, species richness, ecological diversity and habitat dominance. Since the assessment of endemicity and speciosity is necessarily linked to a given geographic area, we here group the first three criteria of Lecointre et al. (2013). Our criteria for a monophletic group (i.e. a clade) are summarized as follows.

Criterion 1 (speciose endemic clade, SEC): the clade is endemic to a delineated geographical area in which it displays an unusually high speciosity (compared to other areas where related clades are found). This is a dual criterion that implies both speciosity (criterion la) and endemicity (criterion $1 \mathrm{~b})$.

Criterion 2 (ecological diversity, ED): the species composing the clade are ecologically well differentiated, occupying a variety of ecological niches.

Criterion 3 (habitat dominance, HD): the clade dominates the habitat, in term of biomass, compared to other taxa.
The concept of a SF is closely related to that of adaptive radiation (AR). ARs are defined as the evolution of high ecological diversity within a rapidly multiplying lineage (Schluter, 2000). This definition, which includes rapidity of diversification, is explicitly based on processes. SFs fulfilling our three criteria (which represents a pattern) could therefore have been generated by recent ARs (i.e. those in which ranges are still endemic to delimited areas), by ARs of poorly dispersing groups or groups distributed in isolated geographical areas (endemicity criterion) or by ARs in extreme environments (where few taxa can survive, making HD more likely). The expression 'species flock' was initially used to refer to the particularly explosive nature of some endemic ARs [see Salzburger \& Meyer (2004), citing Mayr (1942, 1984)]. One question is therefore whether there is underlying unity beneath the $\mathrm{SF}$ concept [based on the detection criteria of Lecointre et al. (2013)]: for example, is there a syndrome, i.e. a significant statistical association among the SEC, ED and HD criteria or is there a single underlying cause leading, in theory, to the joint fulfillment of these three criteria?

To improve our understanding of the processes at the origin of SFs and to investigate whether the three SF criteria are united by a syndrome (pattern) or by a cause (process), we carried out a theoretical analysis of possible processes that could lead to the three SF criteria and a survey of taxa in a single biogeographical context, the Antarctic marine shelf fauna.

First we discuss the evolutionary processes. After reviewing how genetic, ecological, and geographical differentiation may interact, and examining possible feedbacks among SEC, ED and HD, we briefly discuss, for each SF criterion, potential causal evolutionary processes. We distinguish extrinsic factors, related to the environment and the biogeographical framework, from intrinsic factors, related to taxon biological traits. We then examine whether particular conditions or processes could favour the fulfillment of all three criteria simultaneously.

Second, we apply this method to the Antarctic continental shelf system, a large and well-circumscribed region considered as a putative SF generator, where we can assess the effects of shared extrinsic (environmental) factors on a variety of clades displaying a diversity of life-history traits (intrinsic factors). Most previous attempts to analyse the underlying evolutionary processes leading to SFs focus on either terrestrial cases such as island radiations (e.g. Darwin's finches; Grant, 1999) or freshwater taxa. The best-known example is that of the cichlid fish family where hundreds of endemic species are found in the rift lakes of East Africa as a result of an explosive burst of speciation that occurred in the recent past [e.g. during the 100000 years for the cichlid fauna of Lake Victoria (Salzburger, Van Bocxlaer \& Cohen, 2014)]. Microallopatric and sympatric speciation events have been attributed to various causes such as intralacustrine isolation due to fluctuations of water levels, behavioural habitat preferences, and sexual selection (Turner et al., 2001; Salzburger \& Meyer, 2004). No similarly extensive studies or models are available for the evolutionary 
processes causing SFs in the marine realm. Examples are either limited to a narrowly defined geographic area (e.g. the gastropod genus Conus of the Cape Verde archipelago; Duda \& Rolan, 2005), or to single fish taxa [e.g. Sebastes rockfishes in the California Current region (Johns \& Avise, 1998) and Hypoplectrus (hamlets) in Caribbean coral reefs (McCartney et al., 2003)]. The Antarctic continental shelf, a large but well-circumscribed region, is considered as a putative SF generator for a variety of taxa from very different phyla, including notothenioid fish and peracarid crustaceans (Lecointre et al., 2013). This large-scale marine environment represents an interesting model for SF generation as well as for the study of the evolutionary mechanisms underlying diversification in the marine realm. Moreover, it contains various highly divergent, and thus evolutionarily independent, taxa (echinoids, crinoids, fish, crustaceans) with candidate SFs allowing us to investigate the relationship between biological traits (intrinsic factors) and SF criteria more extensively than by focusing on a single taxon.

Finally, we refine the theoretical predictions, propose refinements to the SF concept and suggest directions for future work.

\section{THE PROGESSES OF SF GENERATION}

\section{(1) Genetic, ecological, and geographical differentiation}

\section{(a) Some popular hypotheses on SF causal processes}

Among the processes most often invoked to explain ARs and SFs (as defined above) are ecological opportunity and key innovations, the latter sometimes generating the former (Eastman \& McCune, 2000; Gavrilets \& Losos, 2009; Yoder et al., 2010). The triggering mechanisms can be (i) a new adaptation providing a marked ecological advantage over potential competitors, (ii) colonization of a new environment, and/or (iii) survival of extinction events; all of these are likely to allow access to new ecological niches and to lead to evolutionary success associated with reduced competition. Several studies report habitat shifts associated with bursts of cladogenesis (i.e. speciation events) (Distel et al., 2000; Hou et al., 2011; Corrigan et al., 2014). Key innovations, by definition, clearly explain HD (criterion 3), however their consequences on speciosity (criterion 1a) and ED (criterion 2) are not straightforward. Theoretical and empirical evidence suggest that ecological opportunity generates increasing trait variation, density compensation, and broader habitat use; it is not clear, however, how ecological opportunity leads to speciation and ecological differentiation (Yoder et al., 2010). Increased niche availability (or access to hitherto under-exploited resources) may favour ecological differentiation among species, when intermediate character states are less advantageous for an individual's fitness than extreme states (i.e. in cases of disruptive selection) and if speciation is achieved. However, it is more likely to lead to the superabundance of a generalist species (Abrams, 2006; Yoder et al., 2010). For speciation to be achieved by disruptive selection, mating systems and genetic architecture must allow the erection of prezygotic isolation barriers, i.e. the statistical association of genes or phenotypes involved in assortative mating with those involved in ecological adaptation; this may occur (cf. Appendix 1) when the loci controlling mating and the ecological trait are physically linked, limiting recombination. In such cases of ecological speciation (sympatric or otherwise), there is obviously ecological differentiation among incipient species (criterion 2). Key innovations, or more generally ecological opportunity, are thus not sufficient for a SF to arise. SF formation also requires the establishment of isolation mechanisms among groups of individuals (Mayr, 1984; Salzburger \& Meyer, 2004). Furthermore, isolation among populations of a species may not necessarily be initiated by ecological differentiation, which may instead be a consequence of other types of isolation (see Section 2.1b). Hence, SFs can theoretically form as a result of allopatric speciation followed, after a time lag, by ecological divergence between the newly differentiated species. For instance, oscillations of water levels in African lakes may have produced repeated episodes of allopatry followed by ecological differentiation and SF evolution (Aguilee, Claessen $\&$ Lambert, 2013). Thus key innovations are neither sufficient nor necessary for SF generation.

Considering the endemicity and extreme speciosity of certain SFs relative to the time elapsed since the origin of the clades, many authors have suggested that sympatric speciation is the main driving process involved (Schliewen, Tautz \& Paabo, 1994; Seehausen \& van Alphen, 1999; Turner et al., 2009). Models of sympatric speciation often differed according to whether ecological disruptive selection or assortative mating was considered as the main evolutionary mechanism. Disruptive selection of both ecological and mating traits, however, appears necessary (Weissing, Edelaar \& van Doorn, 2011) since assortative mating must at least partially reflect ecological requirements for sympatric speciation to occur. Interspecific hybridization has been suggested as a potentially common mechanism generating adaptive radiations, because sympatric speciation is more likely to arise when the traits on which disruptive selection acts are determined by the additive effects of many genes, a situation which may be instantaneously generated by a hybridization event (Seehausen, 2004).

\section{(b) Difficulty in identifying initial differentiation mechanisms}

When individuals of two (or more) groups (populations, incipient species or even biological species) differentiate, whatever the nature of the trait involved (genetic, ecological, or geographic), the secondary differentiation of other traits may be enhanced and may occur through genetic drift, or natural or sexual selection. Table 1 presents the different mechanisms by which an initial genetic, ecological or geographic separation among individuals of a species may enhance other types of barriers (or differentiation). Some of the terms used in Table 1 are defined in Appendix 1. Table 1 
shows that ecological differentiation among species of a clade does not imply that speciation was driven by ecological factors in this clade (row 2). For instance, competition among individuals from distinct genetic entities initially formed by allopatric speciation may lead to subsequent ecological differentiation (and ecological diversity) of these entities (Robinson \& Wilson, 1994; Servedio \& Noor, 2003).

Incipient differentiation of one kind within a species may lead to nearly any other type of differentiation as a result of natural selection, mutation, genetic drift, or migration (Table 1). Theory thus predicts a positive feedback between criterion 1 (high species richness of a taxon in an area of endemicity) and criterion 2 (ED). As a consequence, it is difficult to infer rigorously the incipient processes of speciation. The common trend to consider natural selection (adaptation) as the initial driving process of speciation in certain SF and AR literature may not be well founded.

The example of African cichlid fish illustrates how mechanisms at the origin of SFs are difficult to identify. In the phylogeny of these cichlids, deep nodes match habitat differentiation between sand- and rock-dwelling species, intermediate nodes correspond to the partitioning of taxa according to their respective trophic niches, while the most recent nodes distinguish colour morphs (Salzburger, 2009). This pattern is compatible with assortative mating sensu lato as the initial mechanism of differentiation with trophic niche differentiation arising as a consequence of competition among incipient species, both mechanisms occurring sequentially during the course of a given speciation event. However, the pattern is also compatible with an alternative hypothesis where successive speciation events were determined by distinct causes. In this scenario, the first cladogeneses resulted from ecological speciation according to substrate nature, then the differentiation of trophic niches led to subsequent ecological speciation, and, finally, assortative mating (with no apparent ecological diversity) resulted in the most recent speciation events. This latter hypothesis implies three distinct initiating mechanisms for the cladogeneses occurring at different times and may seem less parsimonious. However, it is not necessarily less likely than the former hypothesis because when niches are occupied there is no room for further ecological speciation on this niche component (e.g. substrate), hence another one (e.g. the trophic component) may drive subsequent speciation events. According to Gavrilets \& Losos (2009), mathematical models and data support the following sequence of events during adaptive radiations: (i) divergence with respect to macrohabitats; (ii) evolution of microhabitat choice and divergence with respect to microhabitats; (iii) divergence with respect to ecological traits that simultaneously control the degree of local adaptation and non-random mating; $(i v)$ and divergence with respect to other traits controlling survival and reproduction. In theory, as stated above, both assortative mating and disrupting selection must act in concert to lead to sympatric speciation. In cichlids, sympatric speciation is considered to be the likeliest process at the origin of the radiation. One proximal explanation lies in the strong genetic link (shared genetic basis, pleiotropy) between characters of assortative mating and ecological specialization. For example, the opsin gene controls colour perception which potentially affects both sexual selection (and thus may lead to genetic isolation through assortative mating) and adaptation to distinct environments (ecological differentiation) in terms of depth and turbidity (Terai et al., 2006; Salzburger, 2009). Similarly, the secondary jaw apparatus might be involved both in adaptation to distinct trophic niches (evolution of mouth morphology) and in assortative mating through courtship sounds (Salzburger, 2009). At first sight, explanations that involve only a few genes might sound naive, but rapid and extensive diversification is most likely if the number of underlying loci is small, a pattern observed in cichlid, finch, and monkeyflower ARs (Gavrilets \& Losos, 2009). Cichlid flocks illustrate the variety of factors presumed to be involved in ARs: assortative mating, pleiotropy, diversity of trophic resources and habitat availability. Wagner, Harmon \& Seehausen (2012) report that in African cichlids, only 30 events of lake colonization out of 150 were followed by speciation, and that it was the combination of extrinsic (particularly, lake depth) and intrinsic factors (sexual-selection-related traits) that showed the best statistical association with diversification ability.

\section{(c) Non-independence among SF criteria}

The above considerations suggest that the three criteria, SEC, ED and HD, are not independent characteristics of clades. These interactions are represented in Fig. 1. First, SEC tends to enhance ED when species are sympatric and compete for the same resources. Conversely, when separated species are ecologically diversified in a clade, although speciation rates should not be affected, the extinction rate may be reduced owing to reduced competition among related species, with respect to clades that are less ecologically diversified, so speciosity may increase. There is thus a positive feedback loop between SEC and ED. ED within a clade may also enhance HD at the clade level because the distinct species exploit available resources more efficiently. The reverse relationship is not straightforward. At the species level, habitat-dominant species have larger effective population sizes, all else being equal, increasing the efficiency of natural selection and making ED more likely (see Section 2.2b.iii) but the HD criterion is defined at the clade level. Since a habitat-dominant clade can be composed of non-habitat-dominant species, we thus could not identify general consequences (for a clade) of HD on SEC or on ED.

\section{(2) Extrinsic and intrinsic factors triggering species flock emergence}

Among the possible drivers of SFs (according to the criteria defined in Section 1), it is useful to distinguish between extrinsic and intrinsic factors. Extrinsic factors do not depend on the characteristics of the taxa but are related to geography, environment (biotic and abiotic) and palaeogeographic history. Intrinsic factors are determined by biological traits such as dispersal ability and other life-history traits, ecology 
Table 1. How barriers (ecological, geographical, postzygotic and prezygotic) may interact. This table presents the possible consequences of an initial barrier among groups of individuals (even a partial one) on other barrier types and the evolutionary forces mediating such interactions. The initial barrier or differentiation can be ecological, geographical, postzygotic or prezygotic (see concept definitions in Appendix 1). The evolutionary forces (selection, migration or genetic drift) causing interaction among barrier types are underlined. Differentiation induced by genetic drift (random fluctuations) is generally much slower than differentiation induced by natural selection; the smaller the effective size of the species, the more rapid is differentiation by genetic drift

\begin{tabular}{|c|c|c|c|c|}
\hline $\begin{array}{l}\text { Initial barrier or } \\
\text { differentiation } \rightarrow \\
\text { Induced barrier } \downarrow\end{array}$ & $\begin{array}{l}\text { Ecological (i.e. disruptive } \\
\text { selection) }\end{array}$ & Geographical & Postzygotic & $\begin{array}{c}\text { Prezygotic } \\
\text { (assortative mating) }\end{array}$ \\
\hline Ecological & $\mathrm{X}$ & $\begin{array}{l}\text { If geographic zones have } \\
\text { different (biotic and/or } \\
\text { abiotic) environments } \\
\text { (selection) }\end{array}$ & $\begin{array}{l}\text { By reinforcement if } \\
\text { environment/genetic } \\
\text { architecture allows it } \\
\text { (selection) }\end{array}$ & $\begin{array}{l}\text { If resources are limited: } \\
\text { competition may cause } \\
\text { extinctions or niche } \\
\text { differentiation } \\
\text { (selection) }\end{array}$ \\
\hline Geographical & $\begin{array}{l}\text { If ecological differentiation } \\
\text { corresponds to habitats } \\
\text { with different geographical } \\
\text { distributions } \\
\text { (selection, migration) }\end{array}$ & $\mathrm{X}$ & Not directly & Not directly \\
\hline Postzygotic & $\begin{array}{l}\text { If the ecological trait is } \\
\text { co-dominant, offspring } \\
\text { from crosses between } \\
\text { ecologically differentiated } \\
\text { groups have reduced fitness } \\
\text { (their phenotypes being } \\
\text { intermediate) (selection) }\end{array}$ & $\begin{array}{l}\text { Slowly by genetic drift (at } \\
\text { least) }\end{array}$ & $\mathrm{X}$ & $\begin{array}{l}\text { Slowly by genetic drift } \\
\quad \text { (at least) }\end{array}$ \\
\hline $\begin{array}{l}\text { Prezygotic (assortative } \\
\text { mating) } \\
\text { When complete, leads to } \\
\text { perfect biological species } \\
\text { sensu Mayr (1942) }\end{array}$ & $\begin{array}{l}\text { By reinforcement if } \\
\text { environment/genetic } \\
\text { architecture allows it } \\
\text { (selection) } \\
\text { By ecological (eventually } \\
\text { sympatric) speciation }\end{array}$ & $\begin{array}{l}\text { Slowly by genetic drift (at } \\
\text { least) after a time (longer } \\
\text { than for postzygotic } \\
\text { isolation) Or Indirectly by } \\
\text { reinforcement after } \\
\text { postzygotic isolation (when } \\
\text { in sympatry) (selection) }\end{array}$ & $\begin{array}{l}\text { By reinforcement if } \\
\text { environment/genetic } \\
\text { architecture allows it } \\
\text { (selection) }\end{array}$ & $\mathrm{X}$ \\
\hline
\end{tabular}

and genetic architecture [e.g. when a gene or linkage group encodes phenotypes related to both ecological diversification and assortative mating (e.g. Salzburger, 2009), chromosomal instability or susceptibility to mutations or hybridization].

In Sections II. $2 a$ and $2 b$, factors considered to be good trait predictors are given in italics and underlined; those that appear less influential or for which there is little evidence are in italics but not underlined.

\section{(a) Possible extrinsic factors for each SF criterion}

(i) Speciosity (criterion 1a). A certain degree of habitat fragmentation (e.g. volcanic islands) or a history marked by perturbations, also called active landscape dynamics (climatic or geologic oscillations leading to temporal displacements of physical barriers) (Aguilee et al., 2013), enhance allopatric speciation and thus should increase speciosity. Fragmentation in small areal units, however, may preclude speciation due to insufficient carrying capacity (low local population sizes leading to inbreeding, local extinctions, and thus impeding adaptation). For this reason, some types of insular habitats such as hydrothermal vents or mountaintops appear unlikely to support highly speciose taxa except for very small-sized organisms. Similarly, very rapid landscape dynamics may bring into contact (meta-)populations that are not differentiated enough to possess fully evolved genetic barriers (Aguilee et al., 2013). The relevant range of values for these temporal or spatial fragmentation parameters is not easy to establish a priori and will depend on the biotic characteristics of each taxon, i.e. intrinsic factors, although not in a simple way: e.g. taxa with lower effective population sizes may diverge more rapidly by random genetic drift, and less rapidly by differential adaptation. Seehausen (2004) suggested that hybridization was a potential promoter of ARs, and that it was more likely to occur in peripheral populations such as at distribution range limits, where density is low and competition with parental genotypes may be reduced. Under this hypothesis, limits of biogeographic provinces, such as zones where secondary contacts after recolonization from glacial refugia are likely, would be good candidates.

High speciosity may also be favoured by particularly low extinction rates (where speciation rates are equal) in conditions of long-term environmental stability, as in the South African Cape Poales (Linder \& Bouchenak-Khelladi, 2015).

Mutagenous environments (e.g. intense UV radiation, hydrothermalism; Raupach et al., 2007) may enhance speciation by increasing the rate of divergence and/or by causing chromosomal rearrangements, which may lead to instantaneous speciation (see Section 2.2b). Based on a 30 million year fossil record of three planktonic groups, Allen \& Gillooly (2006) showed a positive correlation between temperature and speciation rates, after controlling for sampling effort and area of available habitat. This fits with their 


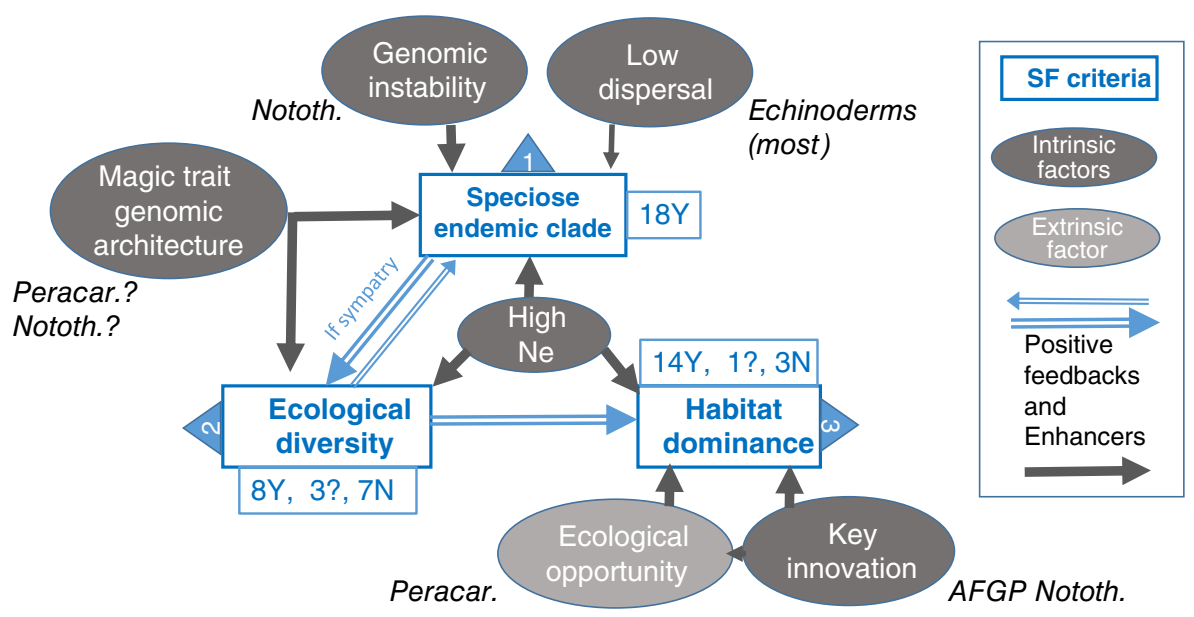

Fig. 1. Interactions among the three species flock (SF) criteria and with factors identified as influential for Antarctic taxa. Main intrinsic factors are in dark-grey ovals ( $\mathrm{Ne}=$ effective population size). Double arrows represent positive feedbacks among criteria (see Section III.1c). Blue items indicate interdependency (i.e. for a clade, fulfilling one of the SF criteria influences fulfillment of another criterion). Solid arrows represent a positive influence of a factor on a criterion. Taxa for which a factor plays an important role are indicated beside the corresponding factor, with a question mark when the influence is putative (Nototh., notothenioids; Peracar., peracarids). The number of clades for which the criterion is fulfilled (Y), not known (?) or not fulfilled (N) is given adjacent to the criterion box. Blue or white text is used for theoretical predictions; black text is used for data from Antarctic taxa. AFGP, antifreeze glycoprotein.

metabolic theory predicting that high temperatures increase mutation rates and thus genetic divergence (but see Section II.2aii for another explanation involving temperature).

There are contradictory predictions regarding the influence of biodiversity level on taxon speciosity. High species richness may $(i)$ allow an increased number of possible niches, which may favour the coexistence of numerous species (e.g. more host taxa for a parasite taxon) but also (ii) increase interspecific competition, which decreases the net diversification rate of a taxon (Rabosky, 2013).

(ii) Endemicity (criterion 1b). Insularity (islands and island-like habitats such as lakes, mountaintops, hydrothermal vents) restricts the possibility of colonization of new areas, thus increasing the probability that a clade remains endemic (MacArthur \& Wilson, 1967). Theoretical models predict, and observations (in fish, snails and lizards) support, that regions of larger areas display higher speciation rates and higher speciosity of endemic taxa (Gavrilets \& Losos, 2009). Warm temperatures induce shorter development times. For species whose dispersal relies on larvae, this leads to shorter dispersal distances (McClain \& Hardy, 2010), favouring speciosity (by allopatric speciation) and endemicity. Reduced developmental times thus may contribute to the effect of temperature on speciosity observed by Allen \& Gillooly (2006).

(iii) Ecological diversity (criterion 2). Niche partitioning within a clade implies that species tend to be specialists rather than generalists. There may thus be environmental features that tend to favour the occurrence of specialist or generalist species. Specialists are expected to be less adapted to changing environments than generalists, and higher turnovers of speciation/extinction rates were shown in specialist taxa (Vrba, 1987; Cantalapiedra, Hernandez
Fernandez \& Morales, 2011; Dennis et al., 2011; Forister et al., 2012; Büchi \& Vuilleumier, 2014). Thus ED should be more frequent in stable environments. According to Kassen's (2002) review of selection experiments, and confirming theoretical predictions, niche width usually evolves to match the amount of environmental variation, with specialists evolving in spatially fine-grained environments and generalists evolving in coarse-grained environments where specialists cannot occupy all of their optimal habitats. Distinct species have distinct mobilities, thus the relevant scale at which to consider environmental heterogeneity depends on the study species. The influence of temporal stability appears more conspicuous than the influence of spatial heterogeneity for specialists/generalists (Büchi \& Vuilleumier, 2014).

An ecosystem displaying high biodiversity (functional and/or specific) offers more potential interactions (biotic and abiotic), and thus more possibilities of niche differentiation (e.g. for trophic specialists) than a low-biodiversity environment (e.g. there are more niches in equatorial forests than in tundra or steppe). For this reason, sister species are less likely to become ecologically differentiated in a low-biodiversity environment. In a functionally complex biotic environment, emerging species are more likely to become specialists than generalists. Theoretical models confirm that more specialized species coexist when the number of interacting species is high (Büchi \& Vuilleumier, 2014).

As discussed in Section I, hybridization may potentially promote ARs and thus ecological diversification. ED is more likely in areas where secondary contacts can occur, for example in zones affected by past fragmentation and that display active landscape dynamics, factors already identified as enhancers of allopatric speciation. To summarize, ED is more likely to occur in stable 
environments, with fine-grained environmental heterogeneity, and in areas of high biodiversity.

(iv) Habitat dominance (in biomass) (criterion 3). In extreme environments, i.e. those with a strongly limiting factor, or where at least one physical factor is extreme, taxa with particular key adaptations with respect to the given environment will by definition arise rarely. When they exist they benefit from a marked advantage and dominate in biomass. Such environments generally harbour less biomass and, with certain exceptions (e.g. the abyssal plains), less biodiversity, in both continental and marine environments (Gibert \& Culver, 2009).

Insularity may indirectly promote HD because low colonization opportunity induces lower biodiversity levels and, in low biodiversity ecosystems, a given species is more likely to dominate.

\section{(b) Possible intrinsic factors for each $S F$ criterion}

In the following we examine large categories of biological traits that are expected, in relatively wide ranges of conditions, to be associated with the SF criteria. Except for dispersal ability regarding criterion 1 (endemicity, speciosity), the literature allows no simple general predictions. This is because different life-history traits of a species do not evolve independently of one another, and are strongly constrained by features of the environment, such as habitat fragmentation and perturbation regimes. Separating them is often unrealistic and simple predictions may appear unreliable. We try below to identify the most important ones.

(i) Speciosity. Lower dispersal ability implies an increase in allopatric speciation rates as well as higher extinction rates, and thus a higher species turnover rate. The outcome on species number will depend on the precise dynamics of speciation/extinction and cannot be generalized easily in the long term. However, a higher turnover of speciation/extinction leads to more closely related species within clades (e.g. Nee, 2001). Since we assess speciosity herein with respect to a circumscribed area of endemicity, and with respect to taxonomically related clades of the same age, criterion la will be enhanced by low dispersal rates. Cichlid fishes and viviparid gastropods of African Lakes (Salzburger et al., 2014) as well as Indonesian brooding gastropods (Von Rintelen \& Glaubrecht, 2005) are salient examples. Brooding clades (lacking a larval dispersal stage) are over-represented in Antarctic invertebrates (Poulin, Palma \& Feral, 2002; Pearse et al., 2009) and many are highly speciose clades or SFs (Lecointre et al., 2013; David et al., 2016). The increase in spatial structuring induced by larval loss is well documented in benthic invertebrates (e.g. Weber et al., 2015).

Theoretical models (e.g. Kirkpatrick \& Barton, 2006) and data show that chromosomal rearrangements enhance speciation, in particular when they restrict recombination, for example in inversions (Faria \& Navarro, 2010; Escudero et al., 2012). The main reason is that meiosis in karyologically heterozygous cells produces aneuploid gametes. Genomic features promoting chromosome rearrangements may thus be considered intrinsic factors promoting speciosity. This may be the case for some genomes with holocentric chromosomes (Hipp, 2007; Hipp, Chung \& Escudero, 2013). For instance a change in chromosome number is associated with a 10 -fold increase in diversification rate in Carex (Escudero et al., 2012).

(ii) Endemicity. Low dispersal acts as an enhancer both directly, by limiting the colonization of new areas, and indirectly, by promoting high species turnover, leading to clades containing younger species than in high-dispersal clades.

(iii) Ecological diversity. ED can occur via ecological specialization. Predicting which biological or life-history traits are associated with narrow niches is not straightforward, and ecological niches have numerous dimensions (e.g. trophic, thermic, etc.) that may vary in size (Hutchinson, 1957). Ecological speciation is one possible process. The probability of ecological speciation events is determined by the genetic architecture underlying assortative mating and the ecological traits under diversifying selection (a certain level of genetic linkage sensu lato among the loci involved in ecological divergence and in assortative mating). An extreme case is represented by so-called 'magic-traits', which are traits subject to divergent selection that pleiotropically affect reproductive isolation (Podos, Dybboe \& Ole Jensen, 2013; Thibert-Plante \& Gavrilets, 2013). Although natural selection impacts genetic architecture once an association exists, the origin of such an association is fortuitous, and hence not predictable, although it is not rare (Servedio et al., 2011). Thus the best way to predict the occurrence of ecological speciation in a taxon is the presence of $\mathrm{AR}$ in related taxa, assuming that genomic architecture is similar in related taxa. This is supported by the literature, including several cases in Antarctic taxa, where taxa containing several clades, sometimes nested, are defined as SFs or at least candidate ARs [e.g. lysianassoid amphipods (Havermans 2012), notothenioids (see Section III.2), cichlids (Salzburger \& Meyer, 2004)].

Ecological speciation and ecological specialization that did not arise by ecological speciation both rely on natural selection. This requires that genetic drift, causing random variation in gene frequencies, is limited (Ohta, 1992). This condition is fulfilled in populations and species with high effective population sizes. Thus, we expect that abundant taxa display ED (among species) more often than rare taxa, everything else being equal. Indirectly, key innovations, given the competitive advantage they provide, are expected to increase effective population sizes and thus ecological speciation (via natural selection), and as a consequence ED.

Taxa involved in close biotic interactions (such as parasitism, symbiosis, or specialized trophic interactions) with a particularly speciose taxon are more likely to display high species richness and ecological diversity, as a result of co-speciation. This mechanism may potentially extend the species richness of a taxon (especially if it is a keystone taxon) to numerous phylogenetically unrelated taxa through a network of biotic interactions. Notothenioid fishes, in which several SFs are described, are hypothesized to have induced ecological specializations and radiations in their amphipod prey (Meyer \& Kassen, 2007; see Section III.2). 
Theory predicts that animals that can search for resources over long periods will be specialists, whereas animals that have limited search times will be generalists; this is supported by generation-time analyses in arthropods (Prinzing, 2003). If the time available to find resources is the key factor, ED will be higher in taxa with high individual mobility: indeed mobility correlates with habitat specialization in European land snails (Dahirel et al., 2015). Note that mobility should not be synonymized with dispersal because mobility can be high in the absence of gene flow (transgenerational effect).

(iv) Habitat dominance. A taxon which develops a key innovation, by definition, obtains a strong ecological advantage and is more likely to dominate the habitat. Can we predict which general intrinsic features favour the occurrence of key innovations? Mutants are more likely to arise in populations of species with large effective sizes, and natural selection is also more efficient in species with large effective population sizes because they display higher genetic diversity and are less subject to genetic drift (Ohta, 1992). Thus a key innovation leading to HD is more likely in species with large effective population sizes. Independently, large body size, high population density, and high fecundity are traits which should favour HD in biomass. However, numerous trade-offs will exist: for instance, (i) populations of large organisms are less dense, in a given environment, so effective population sizes are often much smaller than those of small organisms, and (ii) the trophic level of a species is not a good predictor of its biomass proportion in an ecosystem, impairing predictions based on trophic level.

\section{(c) Transverse analysis of factors and criteria}

The preceding sections outline the most likely factors influencing each criterion. A complementary task is to examine the consequences of each of these major factors, for all criteria (Table 2), not only for the criterion for which a factor was initially identified. High biodiversity in a region should not favour clade speciosity in the case of resource limitation but tends to increase the proportion of specialized clades, indirectly favouring species coexistence. Genome architecture favouring ecological speciation should facilitate HD at the clade level, due to resource partitioning (see Section II.1c). High effective population sizes are expected to favour speciosity (i) by reducing the probability of species extinction, and (ii) by increasing the efficiency of natural selection (Table 1). By contrast, high abundance may indirectly reduce endemicity and facilitate range expansion (when the region considered for this criterion is not isolated by impermeable physical barriers) because gene flow is proportional to effective population size. Key innovations increase the mean adaptive value of a species, and thus its effective population size. As a consequence, the efficiency of natural selection is improved, facilitating ecological speciation, and thus ED among species.

In summary, some factors impact several criteria (Table 2). In many cases, they act in the same direction for different criteria, for instance, fragmentation, low dispersal, and a genomic architecture facilitating ecological speciation all enhance both speciosity and (except for fragmentation) endemicity. By contrast, the HD criterion is never favoured by the extrinsic factors that simultaneously enhance speciosity, endemicity and ED. Based on Table 2, and assuming that all factors identified are equally frequent, 'core' SFs sensu Lecointre et al. (2013) (i.e. fulfilling all criteria except HD) are likely to be relatively frequent and HD is likely to be rare. Only three factors, all intrinsic, favour major SF criteria (i.e. criteria $1 \mathrm{a}, 2$ and 3) simultaneously, although with very unequal predictive value. (i) A genomic architecture favouring ecological speciation is not easy to assess, either it requires genomic studies or is, indirectly, deduced from the presence of several ARs or SFs in a clade through ad hoc reasoning. (ii) Key innovations are not general biological traits and cannot be easily identified based on species biology, the 'key innovation' status being conferred from observation of the SF criterion itself (HD). (iii) By contrast, large effective population size is a general biological trait for which the consequences are well known theoretically and that can be easily assessed by proxies such as abundance or genetic-diversity data. It is often associated with high fecundity and $r$ life-history strategies. However, it theoretically has a negative impact on endemicity, but the importance of endemicity (criterion $1 b$ ) is secondary relative to that of taxon speciosity (criterion 1a) because (i) endemicity assessment is conditional on speciosity, and (ii) most areas studied for their SFs (or putative SFs) are circumscribed by physical barriers (e.g. African Lakes, Antarctic marine biota, archipelagos).

\section{THE ANTARGTIC GASE STUDY}

Focusing on various speciose clades in a single biogeographic region should allow investigation of the role of intrinsic traits, as all clades are subject to similar extrinsic factors. Here we discuss, the extrinsic and intrinsic factors identified in Table 2 with respect to the Southern Ocean and the taxa studied by Lecointre et al. (2013) (Table 3).

\section{(1) Antarctic extrinsic factors and SF criteria}

The Antarctic continental shelf and the Southern Ocean (SO) display extrinsic factors that might have favoured the emergence of SFs. We here identify such factors and discuss their relevance with respect to the three SF criteria used in this study (Table 2).

\section{(a) Fragmentation, landscape dynamics and diversification rates}

The first ice-sheets occurred much earlier (about $34 \mathrm{Mya}$ ) in Antarctica than in the Northern hemisphere (about $8 \mathrm{Mya}$ ) (Zachos et al., 2001; Galeotti et al., 2016; Lear \& Lunt, 2016). At least 38 glacial events have occurred during the last 5 million years in Antarctica (Naish et al., 2008). Glacial cycles are proposed to have favoured diversification of Antarctic marine species via a process named the 'Species Diversity Pump' (Clarke \& Crame, 1992; Thatje, 
Table 2. Effect of intrinsic and extrinsic factors on species flock (SF) criteria: +, enhancing; -, unfavourable or depressing; parentheses indicate a putative or indirect effect (e.g. a consequence of strong positive feedbacks among criteria). In the right-hand column 'yes' or 'no' indicates whether an extrinsic factor is (or is not) more likely to be fulfilled in the Antarctic than in other environments/regions, and taxon names correspond to Antarctic taxa displaying that intrinsic factor. Italic fonts $(+$ or -$)$ show trivial consequences of scale effects (e.g. higher species numbers are expected in larger areas, all else being equal), BUT when there is also a non-trivial component, a black font is used (e.g. species richness per unit area of an island increases with its surface area, larger areas reducing extinction rates). Key innovations are displayed in the bottom row; they should not be considered as general biological traits but rather are hypothesized a posteriori (in the absence of important genomic and phenotypic data). AR, adaptive radiation; EO, ecological opportunity; KI, key innovation

\begin{tabular}{|c|c|c|c|c|c|}
\hline FACTOR & $\begin{array}{l}\text { Speciosity } \\
\text { (criterion la) }\end{array}$ & $\begin{array}{l}\text { Endemicity } \\
\text { (criterion lb) }\end{array}$ & $\begin{array}{l}\text { Ecological } \\
\text { diversity } \\
\text { (criterion 2) }\end{array}$ & $\begin{array}{l}\text { Habitat } \\
\text { dominance } \\
\text { (criterion 3) }\end{array}$ & $\begin{array}{l}\text { Factor status in Antarctic } \\
\text { Shelf }\end{array}$ \\
\hline \multicolumn{6}{|l|}{ Extrinsic factors } \\
\hline $\begin{array}{l}\text { Fragmentation (moderate } \\
\text { to large spatial scale, } \\
\text { present and past) }\end{array}$ & +++ & & $(+)$ & & Yes (historical) \\
\hline $\begin{array}{l}\text { Active landscape } \\
\text { dynamics (not too rapid) }\end{array}$ & +++ & & & & Yes \\
\hline Isolation (insularity) & & +++ & & $(+)$ & Yes \\
\hline Large areal size & + or +++ & ++ or +++ & & - & Yes \\
\hline $\begin{array}{l}\text { Medium- or long-term } \\
\text { environmental stability }\end{array}$ & + & & ++ & & No \\
\hline $\begin{array}{l}\text { Fine-grained } \\
\text { environmental } \\
\text { heterogeneity (relative } \\
\text { to individual mobility) }\end{array}$ & & & + & & $\begin{array}{l}\text { Yes, except for the } \\
\text { least-mobile taxa (which } \\
\text { are numerous) }\end{array}$ \\
\hline High biodiversity & $-($ or $+?)$ & & + & - & $\begin{array}{l}\text { Higher than expected but not } \\
\text { very high }\end{array}$ \\
\hline $\begin{array}{c}\text { Extreme physical } \\
\text { environment }\end{array}$ & & + & & $(+\mathrm{KI}$ or $\mathrm{EO})$ & $\begin{array}{l}\text { Yes (light, seasonality, } \\
\text { temperature) }\end{array}$ \\
\hline High temperatures & ++ & $(+)$ & & & No \\
\hline Mutagenic environment & + & & & & $?(+$ and -$)$ \\
\hline \multicolumn{6}{|l|}{ Intrinsic factors } \\
\hline $\begin{array}{l}\text { Low dispersal ability (gene } \\
\text { flow) }\end{array}$ & +++ & +++ & & & Many brooders \\
\hline Low individual mobility & & & - & & Many benthic invertebrates \\
\hline $\begin{array}{l}\text { Genome instability (sensu } \\
\text { lato) }\end{array}$ & ++ & & & & Notothenioids \\
\hline $\begin{array}{l}\text { Genomic architecture } \\
\text { favouring ecological } \\
\text { speciation }\end{array}$ & ++ & ++ & ++ & $(+)$ & $\begin{array}{l}\geq 3 \text { ARs in notothenioids } \\
\geq 4 \text { ARs in peracarids }\end{array}$ \\
\hline $\begin{array}{l}\text { Strong interactions with } \\
\text { highly speciose taxa or } \\
\text { AR }\end{array}$ & + & & + & & $\begin{array}{l}\text { Epimeriid and iphimediid } \\
\text { amphipods }\end{array}$ \\
\hline $\begin{array}{l}\text { Large effective population } \\
\text { size or abundance }\end{array}$ & $(+)$ & $(-)$ & + & + & $\begin{array}{l}\text { Notothenioids and some } \\
\text { crustaceans }\end{array}$ \\
\hline Key innovations & $(+)$ & & $(+)$ & ++ & Notothenioids \\
\hline
\end{tabular}


Table 3. Survey of marine Antarctic clades and the extrinsic and intrinsic factors that might have favoured the emergence of species flocks (SFs) defined according to the criteria speciosity and endemicity (criterion 1), ecological diversity (criterion 2) and habitat dominance (criterion 3). For taxa that fulfilled at least criterion 1, possible intrinsic factors likely to favour criteria 1, 2 and 3 are reported. In the upper row for each taxon, we indicate whether each criterion was fulfilled. For speciosity, we specify, when possible, whether speciation appears rapid or not, the number of extant species and the age of the last common ancestor of the clade. Note that we do not consider this as a proxy for the explosiveness of the diversification which was assessed independently. In the lower row for each taxon, we report possible intrinsic factors (see Table 2) explaining the criterion status; + or - indicate a positive or negative influence, respectively; factors for which effects are indirect or uncertain are in italics. Note that the absence of candidate intrinsic factors favourable for criterion 2 is because virtually any kind of incipient differentiation can trigger ecological differentiation, and vice versa (see Table 1). AFGP, antifreeze glycoprotein; AR, adaptive radiation; EO, ecological opportunity; GAES, genomic architecture facilitating ecological speciation; KI, key innovation; SO, Southern Ocean

\begin{tabular}{|c|c|c|c|}
\hline Taxon & $\begin{array}{l}\text { Criterion 1: speciosity and } \\
\text { endemicity (in endemic } \\
\text { area of SO or Antarctic Shelf) }\end{array}$ & $\begin{array}{c}\text { Criterion 2: ecological } \\
\text { diversity }\end{array}$ & Criterion 3: habitat dominance \\
\hline \multicolumn{4}{|c|}{ TELEOST FISH } \\
\hline Notothenioidei & $\begin{array}{l}\text { Yes, sudden diversification } \\
\mathbf{1 2 0} \text { species / } 24 \text { Mya (for AFGP-bearing } \\
\text { notothenioids) } \\
\text { (+) Chromosomal/genomic instability } \\
\text { (+) GAES (five SFs, three sudden } \\
\text { diversifications) }\end{array}$ & $\begin{array}{l}\text { Yes } \\
\text { (+) GAES (five SFs, three sudden } \\
\text { diversifications) } \\
\text { (+) facilitated by EO and } K I(A F G P)\end{array}$ & $\begin{array}{l}\text { Yes } \\
(+) \text { KI: AFGP } \\
(+) \text { High effective size (suggested by } \\
\text { high abundances) }\end{array}$ \\
\hline Trematominae & $\begin{array}{l}\text { Yes, sudden diversification } \\
14 \text { species } / 9.1 \text { Mya } \\
\text { As for Notothenioidei }\end{array}$ & $\begin{array}{l}\text { Yes } \\
\text { As for Notothenioidei }\end{array}$ & $\begin{array}{l}\text { Yes } \\
\text { As for Notothenioidei }\end{array}$ \\
\hline Artedidraconinae & $\begin{array}{l}\text { Yes, not a sudden diversification } \\
30 \text { species/3 Mya } \\
\text { Unknown }\end{array}$ & $\begin{array}{l}\text { Yes } \\
\text { As for Notothenioidei }\end{array}$ & $\begin{array}{l}\text { Unknown } \\
\text { As for Notothenioidei except } \\
\text { abundances (no data) }\end{array}$ \\
\hline Channichthyinae & $\begin{array}{l}\text { Yes, not a sudden diversification } \\
17 \text { species/6.3 Mya } \\
\text { Unknown }\end{array}$ & $\begin{array}{l}\text { Yes } \\
\text { As for Notothenioidei }\end{array}$ & $\begin{array}{l}\text { Yes } \\
\text { As for Notothenioidei }\end{array}$ \\
\hline $\begin{array}{l}\text { Pogonophryne } \\
\text { (Artedidraconidae) }\end{array}$ & $\begin{array}{l}\text { Yes, sudden diversification but } \\
\text { possible overestimation by } \\
\text { taxonomy) } \\
22 \text { species/less than } 2 \text { Mya } \\
\text { (-) But constant karyotypes (unlike other } \\
\text { notothenioids) }\end{array}$ & $\begin{array}{l}\text { (-) although live at depth ranges not } \\
\text { colonized by most other notothenioids } \\
\text { which could have led to EO) }\end{array}$ & Unknown \\
\hline \multicolumn{4}{|c|}{ ECHINODERMS } \\
\hline Brooding Schizasteridae & $\begin{array}{l}\text { Yes, not a sudden diversification } \\
\text { ca. } 27 \text { species/ca. } 40 \text { Mya } \\
\text { (+) Low dispersal capability (brooding) } \\
(-) \text { Low mutation rates likely }\end{array}$ & Apparently not & $\begin{array}{l}\text { No (only locally for some } \\
\text { species) } \\
(+) \text { Brooding may favour HD in } \\
\text { less-disturbed habitats (avoids } \\
\text { larval loss and dispersal) }\end{array}$ \\
\hline $\begin{array}{l}\text { Ctenocidarinae } \\
\text { or } \\
\text { Ctenocidarinae minus } \\
\quad \text { Austrocidaris }\end{array}$ & $\begin{array}{l}\text { Yes, but not sudden diversifications } \\
21 \text { or } 20 \text { species (underestimated)/ca. } \\
\quad 34 \text { Mya } \\
\text { (+) Low dispersal capability (brooding) } \\
\text { (-) Low mutation rate likely }\end{array}$ & $\begin{array}{l}\text { No } \\
\text { But scanty data suggest a } \\
\text { diversity of symbiotic } \\
\text { associations }\end{array}$ & No \\
\hline $\begin{array}{l}\text { Clade formed by Promachocrinus } \\
\quad \text { kerguelensis } \\
\text { and } \\
\text { Florometra mazesoni }\end{array}$ & $\begin{array}{l}\text { Yes, unknown suddenness } \\
\text { Eight lineages within two nominal } \\
\text { species } \\
\text { (-) Broadcasting allows high dispersal }\end{array}$ & Unknown & $\begin{array}{l}\text { Yes } \\
\text { (by far the most dominant } \\
\text { crinoid) } \\
\text { (+) High density } \\
\text { (+) Relatively large body size }\end{array}$ \\
\hline Notocrinus & $\begin{array}{l}\text { Yes, unknown suddenness } \\
\text { Nine lineages within two nominal } \\
\text { species } \\
\text { (+) Low dispersal (brooder) }\end{array}$ & Unknown & $\begin{array}{l}\text { Yes } \\
(+) \text { Relatively large body size }\end{array}$ \\
\hline Isometra & $\begin{array}{l}\text { Yes, unknown suddenness } \\
\text { Six nominal species and three lineages } \\
\text { within an additional nominal species } \\
\text { (+) Low dispersal (brooder) }\end{array}$ & $\begin{array}{l}\text { Unknown } \\
\text { (+) Enlarged pinnulars may function in } \\
\text { brood protection }\end{array}$ & (-) Relatively small body size \\
\hline
\end{tabular}


Table 3. Continued

\begin{tabular}{|c|c|c|c|}
\hline Taxon & $\begin{array}{l}\text { Criterion 1: speciosity and } \\
\text { endemicity (in endemic } \\
\text { area of SO or Antarctic Shelf) }\end{array}$ & $\begin{array}{l}\text { Criterion 2: ecological } \\
\text { diversity }\end{array}$ & $\begin{array}{l}\text { Criterion 3: habitat } \\
\text { dominance }\end{array}$ \\
\hline \multicolumn{4}{|c|}{ PERACARIDA $^{(1)}$} \\
\hline Antarctic iphimediid & $\begin{array}{l}\text { Yes, not sudden } \\
>42 \text { species in SO since } 72-34 \text { Mya }\end{array}$ & Not studied & $\begin{array}{l}\text { Yes, in particular areas (as } \\
\text { epibionts) }\end{array}$ \\
\hline Antarctic Orchomene & $\begin{array}{l}\text { Yes }{ }^{(2)} \text { unknown suddenness } \\
\mathbf{3 4} \text { species in SO since } 15.8-3.3 \text { Mya } \\
\text { (+) All brooders, but dispersal ability varies: } \\
\text { low in commensal species } \\
(-) \text { Dispersal ability very high in actively } \\
\text { swimming and swarming scavengers and } \\
\text { predators }\end{array}$ & $\begin{array}{l}\text { Yes } \\
\text { (+) Four AR in Peracarida } \\
\text { (GAES) } \\
(+) \text { High individual mobility in } \\
\text { some cases } \\
(+) \text { Sufficient commensal species } \\
\text { to find their host allowing } \\
\text { specialization } \\
(+) \text { Large effective sizes suggested } \\
\text { by high abundances }\end{array}$ & $\begin{array}{l}\text { Yes } \\
\text { (+) possible KI: swarm-forming habit of } \\
\text { scavengers (anti-predatory behaviour) } \\
\text { (+) Large effective population sizes }\end{array}$ \\
\hline $\begin{array}{l}\text { Perdentatus/Eusirus } \\
\text { (this clade is nested within the } \\
\quad \text { clade below) }\end{array}$ & $\begin{array}{l}\text { Yes, unknown suddenness } \\
\text { Three nominal species, three multiply } \\
\text { cryptic lineages since } 14-4 \text { Mya } \\
\text { (-) Brooders but high dispersal }\end{array}$ & No (or unknown) & $\begin{array}{l}\text { Yes } \\
(+) \text { Large body size }\end{array}$ \\
\hline Antarctic Eusirus & $\begin{array}{l}\text { Yes, unknown suddenness } \\
>55 \text { species }(22 \text { nominal species, } 23 \\
\text { undescribed }) \\
(+/-) \text { Brooders but relatively high dispersal }\end{array}$ & $\begin{array}{l}\text { Yes } \\
\text { ++ all realms } \\
\text { (+) Four ARs in Peracarida } \\
\quad \text { GAES) } \\
(+) \text { Large effective population } \\
\quad \text { size (abundant) } \\
\text { (+) High individual mobility } \\
\quad \text { (good swimmer) }\end{array}$ & $\begin{array}{l}\text { Yes } \\
(+) \text { Some species have very large } \\
\text { body sizes }\end{array}$ \\
\hline Antarctic Epimeria & $\begin{array}{l}\text { Yes, not sudden } \\
26 \text { species }+25 \text { new genetic lineages } \\
\text { since } 34.9-15.7 \text { Mya } \\
\text { Within different species complexes of } \\
\text { Antarctic Epimeria: } 10.28 \text { and } 1.11 \mathrm{Mya} \\
\text { (Verheye et al., } 2016 \text { ) } \\
\text { (+) Brooders and relatively low dispersal and } \\
\text { low individual mobility }\end{array}$ & $\begin{array}{l}\text { Yes } \\
\\
\text { (+) Four ARs in Peracarida } \\
\text { (GAES); large effective } \\
\text { population size (abundant) } \\
\text { (+) Biotic interactions with } \\
\text { known AR or SF Thought to } \\
\text { have co-evolved with } \\
\text { notothenioids (predation } \\
\text { pressure) } \\
(-) \text { Low mobility }\end{array}$ & $\begin{array}{l}\text { (+) possible KI: protection against } \\
\text { predation (spines, armature) } \\
(+) \text { Very large body size for some } \\
\text { species }\end{array}$ \\
\hline Ceratoserolis & $\begin{array}{l}\text { Yes, unknown suddenness } \\
\text { Four species; } \text { C. trilobiotoides } \\
\text { consisting of two lineages } \\
(+) \text { Brooders }\end{array}$ & $\begin{array}{l}\text { No } \\
(+) \text { High abundance suggesting } \\
\text { large effective size }\end{array}$ & $\begin{array}{l}\text { Yes } \\
(+) \text { Large body size }\end{array}$ \\
\hline Glyptonotus & $\begin{array}{l}\text { Yes, unknown suddenness } \\
\text { Minimum of four species } \\
(+) \text { Brooders but some good swimmers (-) } \\
\text { and crawlers }(+)\end{array}$ & $\begin{array}{l}\text { No } \\
(+) \text { High abundance suggesting } \\
\text { large effective size }\end{array}$ & $\begin{array}{l}\text { Yes } \\
(+) \text { Large body size }\end{array}$ \\
\hline Antarctic Serolidae & $\begin{array}{l}\text { Yes, not sudden } \\
\mathbf{8 6} \text { species } \\
(+) \text { Brooders }\end{array}$ & $\begin{array}{l}\text { Yes } \\
(+) \text { Four ARs in Peracarida } \\
\text { (GAES) } \\
\text { (+) Large effective population } \\
\quad \text { size (abundant) }\end{array}$ & $\begin{array}{l}\text { Yes } \\
(+) \text { Possible KI: protection from } \\
\text { predators by flat body shape } \\
(+) \text { Some species have large body size }\end{array}$ \\
\hline
\end{tabular}

(1) Peracarida benefitted from the ecological opportunity provided by decapod extinction in Antarctic waters.

(2) Orchomene is not endemic to Antarctica and its Antarctic component is not monophyletic (see text). 
Hillenbrand \& Larter, 2005) also referred to as the 'Antarctic Continental Shelf' (ACS) hypothesis (Pearse et al., 2009), which states that the shelf region was repeatedly fragmented by ice advances, enhancing allopatric speciation. If this was the major process accounting for Antarctic species-rich clades, we should observe higher diversity on the shelf than on the continental slope or in the deep sea, and diversification events matching Plio-Pleistocene glacial cycles (not older than ca. 2.8 Mya) in species-rich clades. This is not the pattern shown by most speciose clades (Pearse et al., 2009; and Section III.2), although diversity is highest on the continental shelf in amphipods (Havermans, 2014) and polychaetes (Brandt, Linse \& Schüller, 2009), and recent cladogeneses or cryptic species are known or suspected in some peracarids, bivalves, and various echinoderms (Pearse et al., 2009; Hemery et al., 2012; Eléaume et al., 2014; Havermans, 2014; David et al., 2016). Another model of diversification appears convincing for species without larval dispersal (brooders are numerous in the Antarctic benthos). This model relies on the Antarctic Gircumpolar Current (ACG), which originated and strengthened between 34 and $25 \mathrm{Mya}$, and was reinforced 14 Mya (Pearse et al., 2009; Dalziel et al., 2013). It states that individuals of low-dispersal species were brought by the ACC to new locations by rafting, and that allopatric speciation then occurred, dispersal being very rare. This model predicts the highest species diversity along the Scotia Arc and initiation of diversification coinciding with ACG initiation. Both predictions are supported in a variety of invertebrates such as sea urchins (in two distant families of brooders), sea stars, sea cucumbers, brittle stars, and peracarids (Pearse et al., 2009). Secondary contacts in the Atlantic sector of the SO (Drake Passage) between populations on each side of the Polar Front are explained by variations in ACG intensity through time (Wilson, Schroedl \& Halanych, 2009; Diaz et al., 2012; Hüne et al., 2015). Isolation of the Antarctic continent and the strength of the ACC may also have promoted the evolution of 'ring species'. In ring speciation, organisms of a taxon progressively colonize a ring-shaped area (such as an island's coast) from a starting point such that populations that eventually come into contact upon completion of the ring are the most divergent and reproductively isolated. In the octopod species complex Pareledone, haplotypes progressively diverge in a clockwise direction from the South Shetland Islands towards the Amundsen Sea (Allcock et al., 2011). It is possible that this mechanism accounts for speciation of dispersing species along the ACC, although at a slower pace than in the strict ACG model for brooding species.

Isolation of populations associated with founder effects in different refugia over evolutionary timescales might have triggered differential adaptations between prey and predators co-isolated in these disjoint areas: e.g. the sea slug Doris kerguelenensis displays several lineages with distinct anti-predatory secondary metabolites (Wilson, Maschek \& Baker, 2013) that are considered to represent adaptations to specific predators (alternatively, these metabolites may be independent acquisitions acting against the same predators). The physical fragmentation of Antarctica into distinct refugia could thus have allowed ecological adaptation (against different predators) in addition to speciation by co-evolution (species interactions).

\section{(b) Ancient isolation and a large area enhance speciosity and endemicity}

Antarctica is isolated in several ways (Kennett, 1982; Cristini et al., 2012), which strongly promoted endemicity: geological isolation (the Drake passage opened $34 \mathrm{Mya}$; Cristini et al., 2012), climatic isolation (the first ice sheets appeared 38 Mya and most of Antarctica was covered with ice by $14 \mathrm{Mya}$ ), thermal isolation (a rapid temperature decrease about $34 \mathrm{Mya}$ ), and oceanographic isolation (marine fronts and the ACG possibly initiated as soon as the Drake Passage opened). Furthermore, the Antarctic shelves cover an area of $2.2 \times 10^{6} \mathrm{~km}^{2}$ and are located along the $35000 \mathrm{~km}$ coastline of which $45 \%$ is ice shelf (Gutt \& Starmans, 1998). Hospitable terrestrial habitats are sparse due to $99.7 \%$ of the continent being covered by permanent ice and snow (Convey et al., 2008), whereas there has always been an abundance of marine benthic, pelagic and under-ice habitats. Even during glaciations, while most of the shelf area was inhospitable due to the advance of ice shelves, the continental slopes and deep seas provided very large refugia. As discussed in Section II.2a, isolation and large areal sizes can both contribute to high endemicity and high speciosity.

\section{(c) Past environmental instability and the width of ecological niches}

Environmental changes lead to differential extinction and affect specialist species more than generalists (see Section II.2a). On a short timescale, the Antarctic environment is rather stable; compared to other oceans, SO environments are presently characterized by low and stable water temperatures, with a constant temperature of $-1.8^{\circ} \mathrm{C}$ close to the continent (Clarke, 1988). Antarctic organisms are often characterized by a narrow preferred temperature range (Peck, 2002). However, Antarctica is also marked by a seasonal pattern of primary production that strongly influences species biology (Clarke, 1988): several marine invertebrates are seasonally (i.e. in winter) necrophagous, others are characterized by omnivorous and opportunistic diets (e.g. Arnaud, 1977). Over longer timescales, the effects of iceberg scouring are one of the five most significant physical impacts experienced by any ecosystem on Earth (Gutt \& Starmans, 2001) and scouring is considered one of the main driving forces structuring the Antarctic benthos (Gutt \& Piepenburg, 2003). It was estimated that an iceberg impacts any given point on the shelf every 300 years (Gutt, Starmans \& Dieckmann, 1996), affecting the shelf down to 300-600 $\mathrm{m}$ deep (Dowdeswell \& Bamber, 2007). In most cases, only part of the shelf area is affected and recolonization from nearby populations is possible. Such perturbations locally destroy communities but do not change the resources available, so may not be relevant for predicting the frequency of specialist versus generalist species. At an even larger timescale, instability is clearly important in Antarctic environments: the particularly drastic Pleistocene glaciations (see Section III.1a) probably caused many (local or global) extinctions, which may have 
lowered the proportion of specialist taxa both directly and indirectly through biotic interactions (see Section II.2a).

\section{(d) Spatial scale of environmental heterogeneity}

The scale of spatial heterogeneity, i.e. the distribution of resources for individuals, is relevant for predictions of the success of specialist versus generalist lifestyles. Since distinct species are characterized by distinct mobilities, the scale to be considered varies among species. For instance, spatial scales of the order of $<1-100 \mathrm{~m}$ apply to brooding benthic species of macroinvertebrates which do not have dispersing larvae (e.g. Ledoux et al., 2012). Much larger scales (>500 m) will apply to species with planktotrophic larvae. In such species, larval survival and settlement depend strongly on the available resources and substrate nature, thus the larval stage is probably the determinant of the relevant spatial scale to consider rather than the poorly mobile adults. Scouring from grounded, tabular icebergs under direct pressure from the advancing ice shelf creates a disturbed seabed with plough marks, small-scale sediment slumping and elongate depressions (Lien et al., 1989), resulting in a highly heterogeneous habitat. This process generates small zones of up to $40 \mathrm{~m}$ wide in shallow-water communities (Gutt, 2006), which should allow specialists to access suitable resource pools. However, in dense populations of brooding sea urchins, genetic differentiation was observed even between spatially very close individuals, and individual movements may be so limited that even $40 \mathrm{~m}$ may effectively be a coarse grain size (Ledoux et al., 2012). This may apply to the many brooding taxa that are particularly numerous in Antarctic waters (see Section III.1h). If spatial heterogeneity is important, we expect that ecological diversity will be uncommon in the least mobile species. The generality of this conclusion will depend on whether the environmental components that influence ecological diversification have the same scale of heterogeneity as the seabed structure.

\section{(e) Biodiversity in Antarctic marine environments}

The biodiversity latitudinal trend, with decreasing biodiversity towards the poles, has many exceptions. Contradicting energy-limitation theories of species richness, the diversity of the Antarctic benthos does not seem to be limited by competition for food or space (Gutt, 2006). Several taxa are species-rich in the $\mathrm{SO}$ with the most speciose in the benthos including sponges, bryozoans, polychaetes, amphipods and isopods (Clarke \& Crame, 1992; Brandt et al., 2007; De Broyer et al., 2011). Conversely, some marine groups such as benthic decapods, bivalves, gastropods and most groups of marine fish are genuinely depauperate in the SO (Clarke \& Crame, 1992; Chown et al., 2015). The Register of Antarctic Marine Species listed 8294 known and described species in 2011 (De Broyer et al., 2011). Recent studies suggest the presence of many undescribed species (up to $85 \%$ ), as in other understudied environments, and recent extrapolations suggest that 11000-17000 macrobenthic species exist on the Antarctic shelf, classifying it as intermediate in biodiversity compared to tropical, temperate, and Arctic habitats (Gutt et al., 2004). The SO deep sea also displays substantial benthic diversity, at the meio, macro, and mega-faunal levels (Brandt et al., 2007).

\section{(f) Extreme physical factors, key adaptations and ecological opportunity}

Physical factors unique to Polar Regions in general are the polar photoperiod (extreme bi-seasonality) and subzero temperatures close to the continent. Ultraviolet (UV) radiation (during the austral summer) may not be extreme in intensity relative to tropical latitudes but two factors multiply its effects in Antarctic regions: clear water, and recently the partial and fluctuating lack of UV filtering caused by the hole in the ozone layer (see Section III.1g). In response to these extreme environmental conditions, we predict that some clades became dominant following the acquisition of key adaptations allowing them to occupy niches vacated by extinct faunal groups (see Section III.2d). An example of such a key innovation is the antifreeze glycoproteins in notothenioid fish, which prevent tissues from freezing in the subzero, ice-filled waters close to the continent (Devries, 1988). A similar key adaptation evolved independently in the Arctic polar cod (Boreogadus saida) although, interestingly, did not lead there to species diversification (Chen, DeVries \& Cheng, 1997). Another consequence of the extreme Antarctic environment is in ecological opportunity: predators (selacians, most decapods and teleosts) disappeared from the SO between 40 and 34 Mya while other groups started to diversify (Aronson et al., 2009). The absence of durophageous predators that are common elsewhere might thus have allowed the development of the 'Paleozoic-like' benthic community structure (Aronson \& Blake, 2001; Clarke et al., 2004) including filter feeders. The latter may have created microhabitats, providing ecological opportunities for more mobile groups (isopods, amphipods, echinoderms, notothenioids).

\section{(g) Environmental mutagenicity and speciation rates}

Intense UV radiation can cause chromosomal mutation and UV radiation may be extreme in the ice-free zones, particularly now due to ozone-layer depletion. Models indicate that UV-induced mortality of eggs and early life stages of surface-spawning copepods reaches $30 \%$ in subarctic marine systems (Browman et al., 2000; Kuhn et al., 2000). The continuous daylight during the austral summer may enhance this stress. Lamare et al. (2006) investigated the effects of temperature on DNA repair following UV damage in the Antarctic sea urchin Sterechinus neumayeri and found a significantly slower repair rate than in non-Antarctic congeners, possibly explaining the relatively high sensitivity of Antarctic embryos to UV radiation. Such slow rates of DNA repair may lead to higher mutation rates. However, low temperatures may conversely reduce basal mutation rates in the germ line (Allen \& Gillooly, 2006). Whilst there was no evidence for a reduction in mutation rates due to subzero temperatures in crustaceans (Held, 2001), data from two sea urchin families (see Section 
III.2b) do suggest overall lower mutation rates in Antarctic species.

\section{(h) Extrinsic factors shaped similar intrinsic features in various clades}

Indirectly, extrinsic factors may select for the presence of similar intrinsic characteristics in taxa inhabiting the same geographic area: this is probably the case for the relatively high incidence of brooding in Antarctic and sub-Antarctic invertebrates (Poulin et al., 2002; Pearse \& Lockhart, 2004; Pearse et al., 2009). For example, in each of the five classes of Antarctic echinoderms brooding species belong to a few speciose clades, in contrast to echinoderms from other regions where brooders are scattered among different families. This strongly suggests that brooding led to enhanced diversification in the SO. This pattern is attributed to higher extinction rates in species with planktotrophic larvae during glacial episodes (Poulin et al., 2002) when the extension of ice sheets above the water column blocked sunlight, impeding phytoplankton development and consequently larval feeding [see Pearse $e t$ al. (2009) for alternative explanations]. Whatever the explanation, an intrinsic feature (low dispersal ability) arose in several groups independently, presumably as a result of an extrinsic factor. This favoured speciation because low dispersal enhances allopatric differentiation (Pearse et al., 2009).

Other likely impacts of the Antarctic environment on the evolution of biological traits include the cold environment syndrome (e.g. Allen \& Gillooly, 2006). Low metabolic rates and their likely corollary, a long generation time and increased longevity, may result in lower mutation rates in absolute time, even if per-generation rates are unchanged. Mitochondrial sequence data suggest low mutation rates in two unrelated families of brooding sea urchins (Chenuil et al., 2008, 2010; see Section III.2b). The predicted impact is a decrease in speciation rates (all else being equal, because it slows down genetic divergence of populations). The fact that these echinoid families are actually rather speciose compared to non-brooding echinoids (see Section III.2b) may be due to another peculiarity of these families: the dominance of brooding behaviour via its influence on speciation/extinction rates.

\section{(i) Conclusions on Antarctic extrinsic factors}

Certain extrinsic features of Antarctica (i.e. present and past geographic fragmentation, landscape dynamics, isolation, vastness) are likely to have contributed to the production or maintenance of species-rich and endemic taxa (Table 2). By contrast, although the scale of spatial environmental heterogeneity in the benthos appears suitable for specialist species, the perturbed environmental history of Antarctica may rather have impaired ecological diversification within endemic taxa. Similarly, no convincing extrinsic factor is expected to lead to biomass dominance of any taxon, although we suggest that extreme conditions, indirectly, may have allowed rare taxa to benefit from ecological opportunity (perhaps via key innovations) to become dominant in biomass.

Below we consider whether the speciose taxa identified in marine Antarctic waters by Lecointre et al. (2013) corroborate our theoretical predictions concerning intrinsic factors.

\section{(2) Biological (intrinsic) traits of Antarctic marine clades and SF criteria}

The first criterion when considering a taxon is its monophyly, which can be established more reliably when molecular phylogenies are available (Havermans et al., 2010). When based on sufficient markers, molecular phylogenies can reveal putative cryptic species and thus higher taxon speciosity. The taxa discussed below are monophyletic, species-rich, were considered as candidate SFs by Lecointre et al. (2013) and represent the best-studied SO marine metazoans. Table 3 summarizes the evidence for each SF criterion with putative explanatory biological features and, when available, diversification dynamics. We did not consider all clades for which molecular phylogenies were available because data on ecology or diversification dynamics were lacking.

\section{(a) Teleost fish}

Notothenioids have several species-rich clades (Matschiner, Hanel \& Salzburger, 2011; Lautredou et al., 2013; Near et al., 2015) containing ecologically differentiated species that dominate the ecosystem in terms of biomass (i.e. they represent 'full' SFs) (Eastman \& McCune, 2000; Rutschmann et al., 2011). They are endemic to the SO. Most notothenioids (with the exception of three small subantarctic families) have evolved antifreeze glycoproteins (AFGPs). Although the SO has a rather poor ichthyofauna compared to other oceans, notothenioids are a species-rich component (Eastman, 1993, 2005; Lecointre, 2012) representing 134 of the $327 \mathrm{SO}$ fish species and $45.5 \%$ of the known shelf fish species. Their ecological diversity is well known (Eastman, 1993; Klingenberg \& Ekau, 1996; Rutschmann et al., 2011). They account for more than $90 \%$ of the shelf fish biomass (Eastman, 2005). Lecointre et al. (2013) identified five SFs: the AFGP-bearing notothenioids (120 species), within which there are four further $\mathrm{SFs}$, the trematomines, the genus Pogonophryne (all three SFs representing rapid radiations, as revealed by phylogenetic tree shapes or dating), the Channichthyinae and the Artedidraconinae (the latter two $\mathrm{SF}$ do not represent sudden radiations). The common ancestor of AFGP-bearing Antarctic notothenioids has been estimated at about 24 Mya (Matschiner et al., 2011; Near et al., 2015), that of Pogonophryne at less than $2 \mathrm{Mya}$, and that of the Trematominae at 9.1 Mya (Lautredou et al., 2012). Because of a lack of ecological diversity, the Pogonophryne radiation is not identified as a SF and the number of species (22) is probably overestimated in this genus.

AFGPs represent a key innovation (Devries, 1988) and are present in the sister group of Eleginops, a clade termed 'AFGP-bearing notothenioids' by Lecointre (2012), Nototheniidae by Dettai et al. (2012) and Cryonotothenioidea by Near et al. (2015). This clade was considered an AR (Matschiner et al., 2011; Near et al., 2015) and shows a marked increase in diversification rates corresponding to the origin 
of AFGPs in notothenioids and cooling of the Antarctic environment. Karyotypic variability in these Antarctic fish (Pisano \& Ozouf-Costaz, 1998) may have driven their diversification (Tomaszkiewicz et al., 2011). There is clear genomic instability through chromosomal rearrangements and massive transpositions of mobile elements, the latter probably being responsible for the former.

Notothenioids have a dispersal stage with protracted early development from spawning to larvae that develop pelagically over several months (sometimes for up to 2 years) before recruiting to the demersal juvenile population. Despite this potential for extensive dispersal, regionalization of genetic diversity is significant (White, 1998; Patarnello et al., 2003; Van de Putte et al., 2012; Volckaert, Rock \& Van de Putte, 2012). Adult notothenioids have rather low dispersal abilities, except for the few species of the genera Dissostichus and Pleuragramma that re-colonized the pelagic realm.

Large effective sizes are known for some species of the genera Champsocephalus and Dissostichus. Notothenioids dominate the ichthyofauna of the Antarctic shelf not only in terms of biomass (up to $90 \%$ ) but also in terms of numbers of individuals (Eastman, 2005), so large effective population sizes may contribute to their dominance.

\section{(b) Echinoids}

Two independent clades of Antarctic echinoids are particularly speciose and endemic to the SO: the brooding families Schizasteridae and Ctenocidarinae. The two clades do not show high ecological diversity (although in most species of Ctenocidarinae there is a high diversity of symbionts associated with primary spines (sponges, foraminiferans, bryozoans, holothuroids, etc.) but the ecological significance of these symbioses remains unclear). Schizasteridae and Ctenocidarinae species do not show HD in terms of biomass either, with the exception of certain schizasterids, which can dominate benthic habitats in small patches with very dense populations. Molecular phylogenies suggest that both groups diversified about 34 Mya and paleontological data also suggest a time close to $40 \mathrm{Mya}$, i.e. around the onset of the ACG (Pearse et al., 2009; Chenuil et al., 2010; Egea et al., 2016), and the shape of their phylogenetic trees rules out subsequent explosive diversification.

One intrinsic factor probably triggered diversification in both clades: their low dispersal capability, which arose independently in both families likely as a consequence of Antarctic extrinsic factors (see Section III.1h). All species of the two clades brood their young, whereas their respective sister groups are almost exclusively broadcast spawners outside the SO. Low dispersal capabilities were confirmed by population genetics studies in schizasterids (Diaz et al., 2012; Ledoux et al., 2012). Molecular phylogenies of Antarctic Schizasteridae and Ctenocidarinae strongly suggest that these brooding species are more closely related to each other than are species within their sister clades (Lockhart, 2006; Chenuil et al., 2010; Egea et al., 2011); some species even cannot be distinguished by molecular barcoding (Chenuil et al., 2008; Dettai et al., 2011). This supports the hypothesis that their radiation resulted from an increase in speciation/extinction turnover (see Section II.2b), and there is little evidence for the involvement of other factors at least in Ctenocidarinae. For Schizasteridae, locally abundant populations are frequently observed, suggesting that they may have high effective population sizes. The low genetic diversity of these populations is in apparent contradiction with a high effective population size but two molecular analyses revealed that mutation rates are low in Schizasteridae (Chenuil et al., 2008, 2010), which could provide an explanation.

\section{(c) Crinoids}

Although Lecointre et al. (2013) did not classify any of the known Antarctic crinoids as a SF, this interpretation was mainly derived from recognized nominal species. However, considering lineages defined by nucleotide sequences of the mitochondrial cytochrome oxidase subunit 1 as evolutionary units, crinoids can be reanalysed in terms of putative SFs. Thus, recent data suggest that three crinoid taxa can be considered as SF candidates: the genus Isometra, the genus Notocrinus, and the clade Promachocrinus kerguelensis/Florometra maresoni [as defined by Eléaume (2006) and Hemery et al. (2013)]. The genus Isometra (Isometrainae, Antedonidae) is composed of seven species (Clark \& Clark, 1967), most found in the SO. Within these, numerous allopatrically distributed cryptic lineages were recently described using genetic tools (Hemery, 2011; Eléaume et al., 2014), five of which are thought to have arisen within I. graminea. However, two species attributed to this genus (and only known from single specimens) were recorded off Uruguay, and another species occurs in the Weddell Sea and in the deep basins off Brazil and Argentina. The endemicity criterion therefore is challenged for this SF candidate with respect to the SO, but the observed distribution may be a consequence of documented connectivity between the Peninsula area and South America. The genus Notocrinus (Notocrinidae) is monophyletic and endemic to the SO (Hemery, 2011; Hemery et al., 2013). It is composed of two nominal species (Clark \& Clark, 1967) but, as for I. graminea, numerous cryptic lineages were recently identified using molecular tools (Hemery, 2011; Eléaume et al., 2014): two or three within $\mathcal{N}$. mortenseni and 4-6 within $\mathcal{N}$. virilis. Some lineages within $\mathcal{N}$. virilis are sympatric in the Weddell Sea and around the South Shetland Islands. The clade composed of Promachocrinus kerguelensis and Florometra mawsoni, which are sympatric across most of the SO, shows high genetic variability and at least eight mitochondrial lineages (Hemery et al., 2012). Hemery et al. (2012, 2013) concluded that this clade was composed of three species because only three nuclear lineages were identified. However, the absence of reciprocal monophyly in nuclear genes may simply be a consequence of the larger coalescence time of the nuclear genome with respect to the mitochondrial genome (e.g. Egea et al., 2016) and there may indeed be more than three species.

Insufficient data are available on the ecology of these species to allow their ED to be assessed. However, Notocrinus spp. and Promachrocrinus kerguelensis/Florometra mawsoni are 
known to dominate their habitat (Eléaume, 2006; Hemery, 2011).

Biological and ecological processes are not well studied for Antarctic crinoids meaning that only the dispersal ability factor can be addressed. All species within the genus Isometra are brooders and display laterally expanded pinnulars on genital pinnules, and pouches where larvae are retained during part of their development (John, 1938; Clark \& Clark, 1967). They are the only crinoid species in the SO with this sophisticated brooding structure. The juveniles are recruited in the vicinity of the parents which may have favoured the emergence of geographically limited cryptic lineages by allopatric speciation during multiple glacial events. The two Notocrinus species have been described as brooders but evidence of long-distance dispersal events suggests a better dispersal ability than expected for a brooding species and/or rafting events of juveniles or small adults. In view of the number of cryptic lineages highlighted for the two Notocrinus species, their dispersal ability might not have been sufficient to connect isolated populations and prevent allopatric speciation during glacial events. By contrast, species composing the Promachocrinus kerguelensis/Florometra mawsoni clade are broadcast spawners. They are endemic to the SO and are by far the most dominant crinoid species (Eléaume, 2006; Hemery, 2011).

\section{(d) Crustaceans}

For crustaceans, it is interesting to compare the eucarids to the peracarids. In Eucarida, several species show HD (Gutt, Gorny \& Arntz, 1991): Notocrangon antarcticus $\left(73\right.$ specimens $\left./ 100 \mathrm{~m}^{2}\right)$, Chorismus antarcticus (4 specimens $/ \mathrm{m}^{2}$ ) and Nematocarcinus $\left(9\right.$ specimens $\left./ \mathrm{m}^{2}\right)$ but none are from particularly species-rich genera or display substantial ED. By contrast, within Peracarida, or brooding crustaceans, at least two orders (isopods and amphipods) have candidate SFs (Lecointre et al., 2013). Most peracarid families in the SO consist of relatively young (Pleistocene) taxa (Havermans, 2012). Peracarids are particularly speciose in the SO and one hypothesis is that they occupied vacant ecological niches that arose after the extinction of several decapods or benefitted from the absence of these predators, increasing their potential for AR (Brandt, 1999, 2000). For isopods, the Antarctic Serolidae represent a full SF sensu Lecointre et al. (2013), whilst Glyptonotus and Ceratoserolis lack ED. For Antarctic amphipods, Epimeria and Eusirus have been regarded as full SFs (Lecointre et al., 2013), and this may also be the case for the less-studied iphimediids. In particular, Eusirus species show extremely high levels of ecological diversification and have colonized all marine realms: some species utilize the under-ice habitat where they probably feed on ice algae, some are entirely pelagic, whilst others are benthopelagic or benthic; some species are opportunistic scavengers whilst others likely have more specialized feeding. Antarctic orchomenid amphipods (Lysianassoidea) are an example of a diversified group of closely related species; these amphipods were not classified as a SF by Lecointre et al. (2013) due to a lack of monophyly despite all other criteria being met. This group is characterized by a high degree of endemicity in Antarctica, high species richness, HD and ED. They display a wide range of feeding modes and associated morphological adaptations: mucus-feeders (De Broyer, 1985), deposit-feeders (Chevreux, 1903), predators (Dauby, Scailteur \& De Broyer, 2001) and opportunistic (Baird \& Stark, 2013), exclusive (Dauby et al., 2001) or specialized (d'Udekem d'Accoz \& Havermans, 2012) scavengers. Their geographic range is not confined to the $\mathrm{SO}$ and the Antarctic clade appears to be non-monophyletic: some strictly Atlantic (Orchomenella (O.) gerulicorbis, O. (O.) nana) and Arctic (O. pinguis) species were embedded within the strictly Antarctic species (Havermans, 2012). Habitat shifts accompanying (re)colonization events between shallow waters and the deep sea likely favoured species diversification (Havermans, 2012). For orchomenid amphipods, ecological diversification is not confined to the SO: necrophagous specialization is also known in a Northern hemisphere sister-species complex (Moore \& Wong, 1995) and adaptations to a symbiotic lifestyle were observed in a Pacific species (De Broyer \& Vader, 1990). The onset of diversification is estimated at between 34.9 and 15.7 Mya for epimerids, between 71.7 and 34.4 Mya for iphimediids (Lorz \& Held, 2004), and between 15.8 and 3.3 Mya for orchomenids, all within or after the final phase of separation of Antarctica, and for orchomenids, partly overlapping with more recent Pliocene-Pleistocene glacial and interglacial cycles (5 Mya to 12 kya) (Havermans, 2012). Within the different species complexes of Antarctic Epimeria, more recent dates are reported: 10.28 and 1.11 Mya (Verheye, Backeljau \& d'Udekem d'Accoz, 2016).

Several factors may explain how these groups fulfilled the SF criteria.

(1) Dispersal ability. For Eucarida, euphausiids are largely pelagic and efficient swimmers, and decapods are benthic but have planktotrophic larvae. This dispersal ability may explain why they do not show genetic differentiation around the Antarctic continent (Raupach et al., 2010; Bortolotto et al., 2011 ) and are not speciose taxa. By contrast, the peracarids identified as belonging to SFs are all brooders (direct developers), limiting their dispersal other than by rafting (Leese, Agrawal \& Held, 2010). Within peracarids however, dispersal ability varies tremendously. Benthopelagic or pelagic amphipods, such as those of Lysianassoidea or Hyperiidea (Froneman, Pakhomov \& Treasure, 2000) can form dense fast-moving swarms. Even within the Antarctic orchomenids, dispersal ability varies between the extremes of fast-swimming benthopelagic scavengers and predators (Dauby et al., 2001) and commensal species spending their entire life cycle within their host (e.g. Falklandia reducta). The occurrence of (pseudo)cryptic speciation can be linked to both (i) feeding mode, with predators and exclusive scavengers showing genetic homogeneity over large distances and opportunistic scavengers or detritus-feeders showing spatial genetic structuring in several lineages; and (ii) bathymetric distribution, with species restricted to the Antarctic shelf showing a higher occurrence of (pseudo)cryptic speciation (Havermans, 2014). An explanation for the latter may be that 
eurybathic species descended into the deep sea during glacial periods whilst shallow-water species may have undergone more allopatric speciation events due to isolation in the limited number of ice-free shelf refugia (Havermans, 2014).

(2) Presence of an $A R$. Unlike notothenioid fishes, where several $\mathrm{SFs}$ are nested within larger SFs, a single $\mathrm{SF}$ is embedded within a larger one in peracarids (Eusirus perdentatus within Antarctic Eusirus). There is thus no strong support for intrinsic genetic architecture conferring the propensity to form ecologically diversified speciose taxa repeatedly.

(3) Large body size may explain HD in some peracarid SFs. The isopods Glyptonotus spp. and Ceratoserolis trilobitoides are referred to as polar giants (Wagele, 1986; Held, 2003; Held \& Wagele, 2005). Within the amphipods, some iphimediid, Epimeria and Eusirus species can grow very large, and members of the Perdentatus species complex are also giants $(>10 \mathrm{~cm})$ (Chapelle \& Peck, 1999).

(4) Large effective population size. This is particularly true for some orchomenid amphipod species that can reach densities of around 20000 specimens on a single carcass (C. Havermans, personal observations) and hyperiid amphipods, in which swarms of Themisto gaudichaudi can reach similar densities as krill (Froneman et al., 2000). The isopods Ceratoserolis trilobitoides and Glyptonotus antarctus locally dominate the megazoobenthos (Held, 2003; Held \& Wagele, 2005).

(5) Strong biotic interactions with a taxon displaying high speciosity. Several benthic amphipods are thought to have diversified via adaptation to predation by notothenioids (Brandt, 2000), by evolving spines and other armature, or by burrowing into the sediment or sheltering in tubes. Therefore SFs within the notothenioids might have induced, by co-evolutionary processes, morphological and ecological diversity within their prey. Closely related species within the genus of a SF candidate could have evolved ecological diversification through host specialization. In the lysianassoid genus Lepidepecreella, of which some species are obligate parasites of sea urchins, host shifts might have occurred that could have resulted in speciation as a result of the unavailability of a particular host species during glacial cycles (Schiaparelli et al., 2015). Finally, most benthic amphipods, e.g. the Iphimedioidea and Epimeriidae, are 'walker-climber' species, found at different levels in the rich suspension-feeder assemblages. The diversity and complexity of these biotic microhabitats and the abundance of food could have enhanced ecological or morphological diversification in these amphipods (De Broyer et al., 2001).

\section{(3) Lessons from the survey of marine Antarctic clades}

For several speciose taxa, we lack data with which to establish their status relative to $\mathrm{ED}$ or $\mathrm{HD}$, and the nature of their diversification. Nevertheless, an overview of Table 3 and Fig. 1 reveals which of these SF criteria (ED or HD) are most frequently fulfilled and whether distinct criteria are associated within the speciose clades surveyed. Although this cannot be considered a rigorous test, due to missing information and phylogenetic dependency among clades, it does allow a post hoc reconsideration of our tentative theoretical predictions.

HD appears to be the rule rather than the exception, being confirmed in 13 clades and rejected only in three (Table 3). This is surprising since our theoretical review suggested that the HD criterion was influenced by none of the extrinsic factors which enhanced speciosity, endemicity and ED. The high frequency of HD cannot be a consequence of the fact that ED enhances HD (see positive feedbacks in Fig. 1) because five clades with $\mathrm{HD}$ do not display ED [exact tests found no significant association between ED and HD status (results not shown)]. The fact that most clades display HD indirectly supports the prediction that large effective population sizes affect all SF criteria and constitute the only factor favouring simultaneously all criteria (except endemicity) apart from a specific genomic architecture leading to ecological speciation, which is very rare (Fig. 1). However, this observation may also be an artefact because the clades investigated are not a random sample of marine clades but are more likely to belong to the most easily sampled, and thus the most abundant and conspicuous taxa.

Data on rapidity of diversification are rarely available due to incomplete taxon sampling and lack of time calibrations in molecular phylogenies. Nevertheless, this survey shows that the presence of both ED and $\mathrm{HD}$ in speciose clades endemic to the SO, i.e. in full SFs sensu Lecointre et al. (2013) does not imply explosive diversification: at least two fish clades (Artedidraconinae and Channichthyinae) and two peracarid clades (Epimeria and Serolidae) show ED and HD but with no evidence for rapid diversification (Table 3). In Section I, we noted that the first use of the expression 'species flock' was motivated by examples such as the particularly impressive cichlid AR. However, our survey of Antarctic species ruled out explosive speciation in numerous 'full' SFs. We thus question whether there is any underlying unity beneath the SF concept utilizing Lecointre et al. (2013)'s detection criteria. Our survey of SO speciose clades does not support the existence of a syndrome involving the significant association of their criteria (SEC, ED and HD). There may indeed be a single cause leading, in theory, to the joint fulfillment of the three criteria; although our theoretical survey did not identify such a unique factor, ecological speciation is a good candidate process. The intrinsic factor favouring ecological speciation is suitable genomic architecture (see Table 2). The impact of genomic architecture on $\mathrm{HD}$ is admittedly indirect, but since clades with ED are at an advantage regarding $\mathrm{HD}$ (at the clade level), the three criteria of Lecointre et al. (2013) may indeed help to detect clades that have undergone ecological speciation. Note that simply fulfilling the three criteria for a clade does not mean that it underwent ecological speciation, and reciprocally, that ecological speciation does not necessarily lead to speciosity, ED and HD.

Notothenioid fish and peracarid crustaceans display typical ARs and full SFs sensu (Lecointre et al., 2013) at least three and four, respectively. By contrast, the echinoderm species-rich taxa that were analysed display neither 
conspicuous ED nor HD. Echinoderm clades also appear significantly less species-rich, and their diversification rates lower and less sudden than SFs in notothenioids and peracarids. Perhaps as a consequence of Antarctic past environments and history (see Section III. $1 h$ ), many metazoans with a benthic adult phase brood their young and thus have low dispersal abilities in the SO. This is the case in four unrelated echinoderm taxa (Table 3), and in other taxa such as the gastropod species complex Doris kerguelenensis (Wilson et al., 2013). These taxa, however, are species-rich and endemic to Antarctica, compared to their close phylogenetic relatives. Despite our limited knowledge on their ecology, they do not display conspicuous ED: there is a clear contrast between the trophic and morphological specializations shown by members of full SFs such as notothenioids and some peracarid taxa, and the morphological and apparent ecological similarity among schizasterid sea urchins, or among Isometra or Notocrinus crinoids. Only one of these low-dispersal species-rich taxa represents a high biomass (Notocrinus), or they only form dense populations locally and patchily (e.g. Schizasteridae). Some Antarctic echinoid clades that do not brood and are not species-rich have a much higher biomass and abundance than brooding echinoids (David et al., 2005; Saucède et al., 2014).

The Antarctic taxa surveyed probably entered a positive feedback loop (in some cases, leading to SF) in diverse ways. The few intrinsic factors that can explain the main characteristics of speciose clades in Antarctic echinoderms, notothenioids and peracarids are presented in Fig. 1. Low dispersal appears to be the sole factor influencing echinoderm taxa to enter the positive-feedback loop among the SF criteria. But, despite their extremely low dispersal abilities, which may have enhanced speciosity, and the putative snowball effect generated by positive feedbacks among criteria (Fig. 1), these taxa do not show convincing ED, HD or even extreme speciosity. The predicted positive feedbacks therefore do not appear important enough to generate full SFs, at least in these taxa. For notothenioids and peracarids, the extrinsic factor ecological opportunity may explain HD. AFGPs are probably the key innovation that represented an ecological opportunity for AFGP-bearing notothenoids. There is no evidence for similar key innovations in peracarids but the literature suggests a role for ecological opportunity (see Section III. $2 d$ ). Other factors may have enabled these clades to enter the positive feedback loop, that better explain ED and lead to HD: (i) genomic instability (in notothenioids) may have produced instantaneous genetic isolation in sympatric species, which, by competitive exclusion, led to ED, in turn favouring $\mathrm{HD}$ at the clade level; (ii) although difficult to prove in the absence of genomic studies, a genomic architecture favouring ecological speciation may have strongly enhanced ecological diversification and speciation in these clades, as suggested by the presence of a variety of SFs. Alternatively, high effective population sizes may have enabled strong ecological diversification and, as a consequence or independently, high species richness, in these remarkably species-rich and ecologically diversified clades. Indeed, the best explanations for these full SFs involve highly unusual and contingent conditions such as key innovations and chromosomal instability, ecological opportunity, or suitable genomic architecture.

\section{GONGLUSIONS}

(1) Although there are numerous reviews of SFs or ARs in given taxonomic groups, studies focusing on a single geographical region and including several phylogenetically unrelated taxa are rare (Lecointre et al., 2013; Salzburger et al., 2014). Using this approach herein, we established plausible scenarios and refined theoretical predictions. Both theory and our survey of Antarctic taxa strongly support a positive influence of low dispersal ability on speciosity and endemicity. Similarly, past fragmentation and an active landscape history are influential on speciosity. However we could not rigorously test our theoretical predictions due to the absence of detailed ecological information for several groups. For example, a positive influence of high effective population sizes on all criteria for SFs (with the exception of a putative and indirect negative effect on endemicity) is well supported by theory and suggested by our survey of Antarctic clades, but could not be statistically tested.

(2) The fact that in this defined geographic area the 18 speciose clades showed highly contrasting patterns and that several SFs were found in only two taxonomic groups (notothenioids and peracarids) indicates that intrinsic factors are more important than extrinsic factors in predicting the occurrence of full SFs.

(3) Considering that popular explanations for the formation of full SFs that involve unusual phenomena (e.g. sympatric speciation, key innovations) may be naive from an evolutionary point of view (relying on ad hoc explanations), we purposely favoured explanations involving positive feedbacks among criteria (Table 1 and Fig. 1) (combining speciosity, ED and HD) and biological traits and environmental features. Nonetheless, our survey of Antarctic taxa did not uncover such processes. We found a clear difference in diversification speed between the full SFs in notothenioids and peracarids and the other speciose taxa surveyed. For the latter taxa, speciosity and endemicity was generally well explained by their highly reduced dispersal ability (and past Antarctic fragmentation dynamics) but such characteristics did not lead to conspicuous ED and HD. For full SFs however, highly contingent and unusual factors, such as chromosomal instability, key innovation, and possibly also ecological opportunity, provide the most convincing explanations.

(4) The utility of the SF concept is therefore questioned. We showed that the three SF criteria may help to detect clades that have undergone ecological speciation, although the validation of those criteria for a clade does not imply that it has indeed undergone ecological speciation, and vice versa. Therefore, the utility of the SF concept is not clear, especially 
where the concept of AR is already available. However, AR processes do not necessarily lead to HD in biomass, and the use of $\mathrm{HD}$ will result in considering only ARs that gave rise to groups with a significant role in their ecosystem (Odum, 1968). The three qualitative criteria (SEC, ED and HD) in assessing the presence of SFs may be improved by the use of quantitative parameters, particularly concerning diversification rates.

(5) In addition to the echinoderms surveyed here, numerous bentho-pelagic clades have more brooding species on the Antarctic shelf than elsewhere and are likely subject to similar evolutionary processes. A lack of phylogenetic data precluded their inclusion in our survey although it would provide power to statistical analyses of associations among criteria. Molecular phylogenetics, including time calibrations and large-scale taxon sampling could enable more precise quantification of diversification bursts and diversification rates. Now that nuclear DNA sequences are easier to obtain, such data should become increasingly available.

(6) Having entered the 'omics'-era, characterizing the genomic architecture (and identifying features that favour ecological speciation) is now a reachable goal for non-model species. Notothenioid fishes as well as peracarids appear to be interesting models for the application of such methods (Brawand et al., 2014). With such data, scientists could predict whether ecological speciation and thus AR or SFs could arise in a given clade.

(7) Knowledge on biological traits and ecological niche requirements is as important as genetic data to further our understanding of AR and should not be neglected. Assessing ED and HD is not straightforward. Two limiting factors are: $(i)$ the collection of field data, particularly challenging in the Antarctic (but see Danovaro et al., 2016), and (ii) the difficulty of quantifying niche width and niche partitioning consistently among clades (Poisot et al., 2012).

(8) The understanding of diversification processes will benefit from detailed genetic and ecological studies on a given isolated biota. The Antarctic marine realm, isolated geographically for millions of years, represents an excellent model.

\section{AGKNOWLEDGEMENTS}

Knowledge on Antarctic biodiversity has increased due to oceanographic campaigns and scientific programs dedicated to the sampling, inventory and molecular study of marine taxa. We are particularly indebted to the French Agence Nationale de la Recherche (ANR) (grant number "ANTFLOCKS", USAR 07-BLAN-0213-01), to the IPEV programs REVOLTA (\#1124) and PROTEKER (\#1044), the Australian Antarctic Division (CEAMARG cruise) and the SCAR (International Polar Year [CEAMAR IPY\#53], CAML, and current SCAR SRPs AntEco and AnT-ERA). C. H. was supported by the Belgian Science Policy Office (contract $\mathrm{nr}$ BR/132/A1/vERSO) and by the German Science Foundation (DFG, project HA7627/1-1).

\section{REFERENGES}

Abrams, P. A. (2006). Adaptive change in the resource-exploitation traits of a generalist consumer: the evolution and coexistence of generalists and specialists. Evolution $\mathbf{6 0}$, 427-439.

Aguilee, R., Clafssen, D. \& Lambert, A. (2013). Adptive radiation driven by the interplay of eco-evolutionary and landscape dynamics. Evolution 67, 1291-1306.

Allcock, A. L., Barratt, I., Eléaume, M., Linse, K., Norman, M. D., Smith, P. J., Steinke, D., Stevens, D. W. \& Strugnell, J. M. (2011). Cryptic speciation and the circumpolarity debate: a case study on endemic Southern Ocean octopuses using the COI barcode of life. Deep-Sea Research Part II: Topical Studies in Oceanography 58, $242-249$.

Allen, A. P. \& Gillooly, J. F. (2006). Assessing latitudinal gradients in speciation rates and biodiversity at the global scale. Ecology Letters 9, 947-954.

Arnaud, P. (1977). Adaptations within the Antarctic marine benthic ecosystem. In Adaptations within Antarctic Ecosystems (ed. G. A. Llano), pp. 135-137. Smithsonian Institution, Washington.

Aronson, R. B. \& Blake, D. B. (2001). Global climate change and the origin of modern benthic communities in Antarctica. American Zoologist 41, 27-39.

Aronson, R. B., Moody, R. M., Ivany, L. C., Blake, D. B., Werner, J. E. \& GLASs, A. (2009). Climate change and trophic response of the Antarctic bottom fauna. PLoS One 4(2), e4385.

Baird, H. P. \& Stark, J. S. (2013). Population dynamics of the ubiquitous Antarctic benthic amphipod Orchomenella franklini and its vulnerability to environmental change. Polar Biology 36, 155-167.

Bortolotto, E., Bucklin, A., Mezzavilla, M., Zane, L. \& Patarnello, T. (2011). Gone with the currents: lack of genetic differentiation at the circum-continental scale in the Antarctic krill Euphausia superba. BMC Genetics 12:32.

Brandt, A. (1999). On the origin and evolution of Antarctic Peracarida (Crustacea, Malacostraca). Scientia Marina 63, 261-274.

Brandt, A. (2000). Hypotheses on Southern Ocean peracarid evolution and radiation Crustacea, Malacostraca). Antarctic Science 12, 269-275.

Brandt, A., Gooday, A. J., Brandao, S. N., Brix, S., Broekeland, W., Cedhagen, T., Choudhury, M., Cornelius, N., Danis, B., De Mesel, I., Diaz, R. J., Gillian, D. C., Ebbe, B., Howe, J. A., Janussen, D., et al. (2007). First insights into the biodiversity and biogeography of the Southern Ocean deep sea. Nature 447, 307-311.

Brandt, A., Linse, K. \& Schüller, M. (2009). Bathymetric distribution patterns of Southern Ocean macrofaunal taxa: Bivalvia, Gastropoda, Isopoda and Polychaeta Deep Sea Research Part I: Oceanographic Research Papers 56, 2013-2025.

Brawand, D., Wagner, C. E., Li, Y. I., Malinsky, M., Keller, I., Fan, S., Simakov, O., NG, A. Y., Lim, Z. W. \& Bezault, E. (2014). The genomic substrate for adaptive radiation in African cichlid fish. Nature 513, 375-381.

Browman, H. I., Rodriguez, C. A., Beland, F., Cullen, J. J., Davis, R. F. Kouwenberg, J. H. M., Kuhn, P. S., McArthur, B., Runge, J. A., St-Pierre, J. F. \& VETTER, R. D. (2000). Impact of ultraviolet radiation on marine crustacean zooplankton and ichthyoplankton: a synthesis of results from the estuary and Gulf of St. Lawrence, Canada. Marine Ecology Progress Series 199, 293-311.

BüCHI, L. \& Vuilleumier, S. (2014). Coexistence of specialist and generalist species is shaped by dispersal and environmental factors. American Naturalist 183, 612-624.

Butlin, R. (1987). Speciation by reinforcement. Trends in Ecology Ë Evolution 2, 8-13.

Cantalapiedra, J. L., Hernandez Fernandez, M. \& Morales, J. (2011). Biomic specialization and speciation rates in ruminants (Cetartiodactyla, Mammalia): a test of the resource-use hypothesis at the global scale. PLoS One 6(12), e28749.

Chapelle, G. \& Peck, L. S. (1999). Polar gigantism dictated by oxygen availability. Nature 399, 114-115

Chen, L. B., DeVries, A. L. \& Cheng, C. H. C. (1997). Convergent evolution of antifreeze glycoproteins in Antarctic notothenioid fish and Arctic cod. Proceedings of the National Academy of Sciences of the United States of America 94, 3817-3822.

Chenuil, A., Egea, E., Rocher, G. \& Feral, J.-P. (2010). Comparing substitution rates in spatangoid sea urchins with putatively different effective sizes, and other echinoderm datasets. In Echinoderms: Durham (eds L. G. Harris, S. A. Bottger, G. W. WAlker and M. P. Lesser), pp. 159-161. Taylor \& Francis Group, London.

Chenuil, A., Egea, E., Rocher, C., Touzet, H. \& Feral, J.-P. (2008). Does hybridization increase evolutionary rate? Data from the 28S-rDNA D8 domain in echinoderms. Fournal of Molecular Evolution 67, 539-550.

Chevreux, E. (1903). Campagnes scientifiques de S.A. le P. Albert Ier de Monaco. Note preliminaire sur les amphipodes de la famille des Lysianassidae recueillis par la «Princesse Alice » dans les eaux profondes de l'Atlantique et de la Méditerranée. Bulletin de la Société Zoologique de France 28, 81-97.

Chown, S. L., Clarke, A., Fraser, C. I., Cary, S. C., Moon, K. L. \& McGeoch, M. A. (2015). The changing form of Antarctic biodiversity. Nature 522, 431-438.

Clark, A. H. \& Clark, A. M. (1967). A monograph of the existing crinoids, Vol. 1: the comatulids, part 5, Suborders Oligophreata (concluded) and Macrophreata. Bulletin of the United States National Museum 82, 1-795.

Clarke, A. (1988). Seasonality in the Antarctic marine environment. Comparative Biochemistry and Physiology Part B: Biochemistry \& Molecular Biology 90, 461-473. 
Clarke, A., Aronson, R. B., Crame, J. A., Gil, J. M. \& Blake, D. B. (2004). Evolution and diversity of the benthic fauna of the Southern Ocean continental shelf. Antarctic Science 16, 559-568.

Clarke, A. \& Crame, J. (1992). The Southern-Ocean benthic fauna and climate change - a historical-perspective. Philosophical Transactions of the Royal Society of London Series B: Biological Sciences 338, 299-309.

Convey, P., Gibson, J. A. E., Hillenbrand, C.-D., Hodgson, D. A., Pugh, P. J. A., Smellie, J. L. \& Stevens, M. I. (2008). Antarctic terrestrial life - challenging the history of the frozen continent? Biological Revieres 83, 103-117.

Corrigan, L. J., Horton, T., Fotherby, H., White, T. A. \& Hoelzel, A. R. (2014). Adaptive evolution of deep-sea amphipods from the superfamily Lysiassanoidea in the North Atlantic. Evolutionary Biology 41, 154-165.

Cristini, L., Grosfeld, K., Butzin, M. \& Lohmann, G. (2012). Influence of the opening of the Drake Passage on the Cenozoic Antarctic Ice Sheet: a modeling approach. Palaeogeography Palaeoclimatology Palaeoecology 339, 66-73.

Dahirel, M., Olivier, E., Guiller, A., Martin, M.-C., Madec, L. \& Ansart, A. (2015). Movement propensity and ability correlate with ecological specialization in European land snails: comparative analysis of a dispersal syndrome. Fournal of Animal Ecology 84, 228-238.

Dalziel, I. W. D., Lawver, L. A., Pearce, J. A., Barker, P. F., Hastie, A. R., Barfod, D. N., Schenke, H. W. \& Davis, M. B. (2013). A potential barrier to deep Antarctic circumpolar flow until the late Miocene? Geology 41, 947-950.

Danovaro, R., Carugati, L., Berzano, M., Cahill, A. E., Carvalho, S., Chenuil, A., Corinaldesi, C., Cristina, S., Davidson, R., Dell'Anno, A., Dzhembekova, N., Garcès, E., Gasol, J. M., Goela, P., Féral, J.-P., et al. (2016). Implementing and innovating marine monitoring approaches for assessing marine environmental status. Frontiers in Marine Science 3, 213.

Dauby, P., Scailteur, Y. \& De Broyer, C. (2001). Trophic diversity within the eastern Weddell Sea amphipod community. Hydrobiologia 443, 69-86.

David, B., Choné, T., Mooi, R. \& De Ridder, C. (2005). Antarctic Echinoidea. In Synopses of the Antarctic Benthos (Volume 10, eds J. W. WÄGELE and J. SIEG). ARG Gantner Verlag KG, Lichtenstein.

David, B., Saucède, T., Chenuil, A., Steimetz, E. \& De Ridder, C. (2016). The taxonomic challenge posed by the Antarctic echinoids Abatus bidens and Abatus cavernosus (Schizasteridae, Echinoidea). Polar Biology 39, 897-912.

De Broyer, C. (1985). Description de Falklandia gen. n. de l'Océan Austral et définition des Lysianassoidea uristidiens (Crustacea: Amphipoda). Zoologica Scripta 14(4), $303-312$.

De Broyer, C., Danis, B., Allcock, L., Angel, M., Arango, C., Artois, T., Barnes, D., Bartsche, I., Bester, M. \& Blachowiak-Samolyk, K. (2011). How many species in the Southern Ocean? Towards a dynamic inventory of the Antarctic marine species. Deep-Sea Research Part II: Topical Studies in Oceanography 58, $5-17$.

De Broyer, G., Scailteur, Y., Chapelle, G. \& Rauschert, M. (2001). Diversity of epibenthic habitats of gammaridean amphipods in the eastern Weddell Sea. Polar Biology 24, 744-753.

De Broyer, C. \& VAder, W. (1990). Revision and notes on the biology of Orchomenella recondita (Stasek, 1958) (Amphipoda, Lysianassoidea) an associate of sea anemones. Beaufortia 41, 31-38.

Dennis, R. L. H., Dapporto, L., Fattorini, S. \& Cook, L. M. (2011). The generalism-specialism debate: the role of generalists in the life and death of species. Biological Journal of the Linnean Society 104, 725-737.

Dettai, A., Adamowizc, S. J., Allcock, L., Arango, C. P., Barnes, D. K. A., Barratt, I., Chenuil, A., Couloux, A., Cruaud, C., David, B., Denis, F., Denys, G., Díaz, A., Eléaume, M., Féral, J.-P., et al. (2011). DNA barcoding and molecular systematics of the benthic and demersal organisms of the CEAMARC survey. Polar Science 5, 298-312.

Dettai, A., Berkani, M., Lautredou, A.-C., Couloux, A., Lecointre, G., Ozouf-Costaz, C. \& Gallut, C. (2012). Tracking the elusive monophyly of nototheniid fishes (Teleostei) with multiple mitochondrial and nuclear markers. Marine Genomics 8, 49-58.

Devries, A. L. (1988). The role of antifreeze glycopeptides and peptides in the freezing avoidance of Antarctic fishes. Comparative Biochemistry and Physiology B: Biochemistry \& Molecular Biology 90, 611-621.

Diaz, A., Alejandro Gonzalez-Wevar, C., Maturana, C. S., Palma, A. T., Poulin, E. \& Gerard, K. (2012). Restricted geographic distribution and low genetic diversity of the brooding sea urchin Abatus agassizii (Spatangoidea: Schizasteridae) in the South Shetland Islands: a bridgehead population before the spread to the northern Antarctic Peninsula? Revista Chilena de Historia Natural 85, 457-468.

Distel, D. L., Baco, A. R., Chuang, E., Morrill, W., Cavanaugh, C. \& Smith, C. R. (2000). Marine ecology - do mussels take wooden steps to deep-sea vents? Nature 403, 725-726.

Dowdeswell, J. A. \& Bamber, J. L. (2007). Keel depths of modem Antarctic icebergs and implications for sea-floor scouring in the geological record. Marine Geology 243, $120-131$.

Duda, T. F. \& Rolan, E. (2005). Explosive radiation of Cape Verde Conus, a marine species flock. Molecular Ecology 14, 267-272.
D'Udekem D'Accoz, C. \& Havermans, C. (2012). Two new Pseudorchomene species from the Southern Ocean, with phylogenetic remarks on the genus and related species (Crustacea: Amphipoda: Lysianassoidea: Lysianassidae: Tryphosinae). Zootaxa 3310, 1-50.

Eastman, J. T. (1993). Antarctic Fish Biology: Evolution in a Unique Environment. Academic Press, New York.

Eastman, J. T. (2005). The nature of the diversity of Antarctic fishes. Polar Biology 28, 93- 107.

Eastman, J. T. \& McCune, A. (2000). Fishes on the Antarctic continental shelf: evolution of a marine species flock? Journal of Fish Biology 57, 84-102.

Egea, E., David, B., Chone, T., Laurin, B., Feral, J. P. \& Chenuil, A. (2016). Morphological and genetic analyses reveal a cryptic species complex in the echinoid Echinocardium cordatum and rule out a stabilizing selection explanation. Molecular Phylogenetics and Evolution 94, 207-220.

Egea, E., Merigot, B., Mahe-Bezac, C., Feral, J.-P. \& Chenuil, A. (2011). Differential reproductive timing in Echinocardium spp.: the first Mediterranean survey allows interoceanic and interspecific comparisons. Comptes Rendus Biologies 334, $13-23$.

ElÉAume, M. (2006). Approche morphométrique de la variabilité phénotypique : conséquences systématiques et évolutives. Application aux crinoüdes actuels (Crinoidea : Echinodermata). $\mathrm{PhD}$ Dissertation: Muséum National d'Histoire Naturelle, Paris

Eléaume, M., Hemery, L., Roux, M. \& Ameziane, N. (2014). Chapter 10.7. Phylogeographic patterns of the Southern Ocean Crinoids (Crinoidea: Echinodermata). In Biogeographic Atlas of the Southern Ocean (eds C. DE Broyer, P. Koubbi, H. J. Griffiths, B. Raymond, C. Udekem D'Acoz, A. P. Van de Putte, B. Danis, B. David, S. Grant, J. Gutt, C. Held, G. Hosie, F. Huettmann, A. Post and Y. Ropert-Coudert), pp. 448-455. Scientific Committee on Antarctic Research, Cambridge.

Escudero, M., Hipp, A. L., Waterway, M. J. \& Valente, L. M. (2012). Diversification rates and chromosome evolution in the most diverse angiosperm genus of the temperate zone (Carex, Cyperaceae). Molecular Phylogenetics and Evolution 63, 650-655.

FARIA, R. \& Navarro, A. (2010). Chromosomal speciation revisited: rearranging theory with pieces of evidence. Trends in Ecology \& Evolution 25, 660-669.

Forister, M. L., Dyer, L. A., Singer, M. S., Stireman, J. O. III \& Lill, J. T. (2012). Revisiting the evolution of ecological specialization, with emphasis on insect-plant interactions. Ecology 93, 981-991.

Froneman, P. W., Pakhomov, E. A. \& Treasure, A. (2000). Trophic importance of the hyperiid amphipod, Themisto gaudichaudi, in the Prince Edward Archipelago (Southern Ocean) ecosystem. Polar Biology 23, 429-436.

Galeotti, S., DeConto, R., Naish, T., Stocchi, P., Florindo, F., Pagani, M., Barrett, P., Bohaty, S. M., Lanci, L., Pollard, D., Sandroni, S., TAlarico, F. M. \& Zachos, J. G. (2016). Antarctic Ice Sheet variability across the Eocene-Oligocene boundary climate transition. Science 352, 76-80.

Gavrilets, S. \& Losos, J. B. (2009). Adaptive radiation: contrasting theory with data. Science $323,732-737$

Gibert, J. \& Culver, D. C. (2009). Assessing and conserving groundwater biodiversity: an introduction. Freshwater Biology 54, 639-648.

Grant, P. R. (1999). Ecology and Evolution of Darwin's Finches. Princeton University Press. Princeton, NJ.

Greenwood, P. (1984). What is a species flock? In Evolution of Fish Species Flocks (eds A. A. Echelle and I. Kornfield), pp. 13-19. University of Maine, Orono Press. Orono, Maine.

GutT, J. (2006). Coexistence of macro-zoobenthic species on the Antarctic shelf: an attempt to link ecological theory and results. Deep-Sea Research Part II: Topical Studies in Oceanography 53, 1009-1028.

Gutt, J., Gorny, M. \& Arntz, W. (1991). Spatial distribution of Antarctic shrimps (Crustacea, Decapoda) by underwater photography. Antarctic Science 3, 363-369.

Gutt, J. \& Piepenburg, D. (2003). Scale-dependent impact on diversity of Antarctic benthos caused by grounding of icebergs. Marine Ecology Progress Series 253, 77-83.

Gutt, J., Sirenko, B. I., Smirnov, I. S. \& Arntz, W. E. (2004). How many macrozoobenthic species might inhabit the Antarctic shelf? Antarctic Science 16, $11-16$.

Gutt, J. \& Starmans, A. (1998). Structure and biodiversity of megabenthos in the Weddell and Lazarev Seas (Antarctica): ecological role of physical parameters and biological interactions. Polar Biology 20, 229-247.

GutT, J. \& Starmans, A. (2001). Quantification of iceberg impact and benthic recolonisation patterns in the Weddell Sea (Antarctica). Polar Biology 24, 615-619.

Gutt, J., Starmans, A. \& Dieckmann, G. (1996). Impact of iceberg scouring on polar benthic habitats. Marine Ecology Progress Series 137, 311-316.

Havermans, C. (2012). DNA barcoding, phylogeography and phylogeny of the Lysianassoidea (Crustacea: Amphipoda) from the Southern Ocean and the World's deep seas. PhD Thesis: Université catholique de Louvain.

Havermans, C. (2014). Chapter 10.6. Phylogeographic patterns of the Lysianassoidea (Crustacea: Peracarida: Amphipoda). In Biogeographic Atlas of the Southern Ocean (eds C. De Broyer, P. Koubbi, H. J. Griffiths, B. Raymond, C. Udekem d'Acoz, A. P. Van de Putte, B. Danis, B. David, S. Grant, J. Gutt, C. Held, G. Hosie, 
F. Huettmann, A. Post and Y. Ropert-Coudert), pp. 441-447. Scientific Committee on Antarctic Research, Cambridge.

Havermans, G., Nagy, Z. T., Sonet, G., De Broyer, G. \& Martin, P. (2010). Incongruence between molecular phylogeny and morphological classification in amphipod crustaceans: a case study of Antarctic lysianassoids. Molecular Phylogenetics and Evolution 55, 202-209.

HELD, C. (2001). No evidence for slow-down of molecular substitution rates at subzero temperatures in Antarctic serolid isopods (Crustacea, Isopoda, Serolidae). Polar Biology 24, 497-501.

HeLd, C. (2003). Molecular evidence for cryptic speciation within the widespread Antarctic crustacean Ceratoserolis trilobitoides (Crustacea, Isopoda). In Antarctic Biology in a Global Context (eds A. H. L. Huiskes, W. W. C. Gieskes, J. Rozema, R. M. L. Schorno, S. M. van der VRies and W. J. WolfF), pp. 305-310. Backhuys Publishers, Leiden.

Held, C. \& WAgele, J. W. (2005). Cryptic speciation in the giant Antarctic isopod Glyptonotus antarcticus (Isopoda : Valvifera : Chaetiliidae). Scientia Marina 69, 175-181.

Hemery, L. G. (2011). Diversité moléculaire, phylogéographie et phylogénie des Crinoïdes (Echinodermes) dans un environnement extrême : l'océan Austral. PhD Dissertation: Muséum National d'Histoire Naturelle, Paris.

Hemery, L. G., Eléaume, M., Roussel, V., Ameziane, N., Gallut, C., Steinke, D., Cruaud, C., Couloux, A. \& Wilson, N. G. (2012). Comprehensive sampling reveals circumpolarity and sympatry in seven mitochondrial lineages of the Southern Ocean crinoid species Promachocrinus kerguelensis (Echinodermata). Molecular Ecology 21, 2502-2518.

Hemery, L. G., Roux, M., Ameziane, N. \& Eléaume, M. (2013). High-resolution crinoid phyletic inter-relationships derived from molecular data. Cahiers de Biologie Marine 54, 511-523.

HIPP, A. L. (2007). Nonuniform processes of chromosome evolution in sedges (Carex: Cyperaceae). Evolution 61, 2175-2194.

Hipp, A. L., Chung, K. \& Escudero, M. (2013). Holocentric chromosomes. In Brenner's Encyclopedia of Genetics. Second Edition (eds S. MaLOY and K. Hughes), pp. 499-501. Academic Press, Cambridge Massachusetts.

Hou, Z., SKet, B., FišEr, C. \& Li, S. (2011). Eocene habitat shift from saline to freshwater promoted Tethyan amphipod diversification. Proceedings of the National Academy of Sciences of the United States of America 108, 14533-14538.

Hüne, M., Gonzalez-Wevar, G., Poulin, E., Mansilla, A., Fernandez, D. A. \& BARRERA-ORO, E. (2015). Low level of genetic divergence between Harpagifer fish species (Perciformes: Notothenioidei) suggests a Quaternary colonization of Patagonia from the Antarctic Peninsula. Polar Biology 38, 607-617.

Hutchinson, G. (1957). Population studies - animal ecology and demography - concluding remarks. Cold Spring Harbor Symposia on Quantitative Biology 22, $415-427$

John, D. (1938). Crinoidea. Discovery Reports 18, 121-222.

JoHns, G. C. \& Avise, J. C. (1998). Tests for ancient species flocks based on molecular phylogenetic appraisals of Sebastes rockfishes and other marine fishes. Evolution 52, $1135-1146$.

Kassen, R. (2002). The experimental evolution of specialists, generalists, and the maintenance of diversity. Foumal of Evolutionary Biology 15, 173-190.

Kennett, J. (1982). Marine Geology. Prentice-Hall, Englewood Cliffs.

Kirkpatrick, M. \& Barton, N. (2006). Chromosome inversions, local adaptation and speciation. Genetics 173, 419-434.

KlingenberG, C. P. \& EKAU, W. (1996). A combined morphometric and phylogenetic analysis of an ecomorphological trend: Pelagization in Antarctic fishes (Perciformes: Nototheniidae). Biological Foumal of the Linnean Society 59, 143-177.

Kuhn, P. S., Browman, H. I., Davis, R. F., Cullen, J. J. \& McArthur, B. L. (2000). Modeling the effects of ultraviolet radiation on embryos of Calanus finmarchicus and Atlantic cod (Gadus morhua) in a mixing environment. Limnology and Oceanography 45, 1797-1806.

Lamare, M. D., Barker, M. F., Lesser, M. P. \& Marshall, C. (2006). DNA photorepair in echinoid embryos: effects of temperature on repair rate in Antarctic and non-Antarctic species. Fournal of Experimental Biology 209, 5017-5028.

Lautredou, A. C., Hinsinger, D. D., Gallut, C., Cheng, C. H. C., Berkani, M., Ozouf-Costaz, G., Cruaud, C., Lecointre, G. \& Dettai, A. (2012). Phylogenetic footprints of an Antarctic radiation: the Trematominae (Notothenioidei, Teleostei). Molecular Phylogenetics and Evolution 65, 87-101.

Lautredou, A. C., Motomura, H., Gallut, C., Ozouf-Costaz, C., Cruaud, C., Lecointre, G. \& DettaI, A. (2013). New nuclear markers and exploration of the relationships among Serraniformes (Acanthomorpha, Teleostei): the importance of working at multiple scales. Molecular Phylogenetics and Evolution 67, 140-155.

Lear, C. H. \& Lunt, D. J. (2016). How Antarctica got its ice. Science 352, 34-35.

Lecointre, G. (2012). Phylogeny and systematics of Antarctic teleosts: methodological and evolutionary issues. In Adaptation and Evolution in Marine Environments (Volume 1, eds G. Di Prisco and C. VerdE), pp. 97-117. Springer, Berlin.

Lecointre, G., Ameziane, N., Boisselier, M.-C., Bonillo, C., Busson, F., Causse, R., Chenuil, A., Couloux, A., Coutanceau, J.-P., Cruaud, C., D’Udekem d'Acoz, C., De Ridder, C., et al. (2013). Is the species flock concept operational? The Antarctic shelf case. PLoS One 8, e68787.
Ledoux, J.-B., Tarnowska, K., Gerard, K., Lhuillier, E., Jacouemin, B. Weydmann, A., Feral, J.-P. \& Chenuil, A. (2012). Fine-scale spatial genetic structure in the brooding sea urchin Abatus cordatus suggests vulnerability of the Southern Ocean marine invertebrates facing global change. Polar Biology 35, 611-623.

Leese, F., Agrawal, S. \& Held, C. (2010). Long-distance island hopping without dispersal stages: transportation across major zoogeographic barriers in a Southern Ocean isopod. Naturwissenschaften 97, 583-594.

Lien, R., Solheim, A., Elverh $\varnothing$ I, A. \& Rokoengen, K. (1989). Iceberg scouring and sea bed morphology on the eastern Weddell Sea shelf, Antarctica. Polar Research 7, 43-57.

Linder, H. P. \& Bouchenak-Khelladi, Y. (2015). The causes of southern African spatial patterns in species richness: speciation, extinction and dispersal in the Danthonioideae (Poaceae). Fournal of Biogeography 42, 914-924.

Lockhart, S. J. (2006). Molecular evolution, phylogenetics, and parasitism in Antarctic cidaroid echinoids. PhD Thesis: University of California, Santa Cruz.

Lorz, A. N. \& HeLd, C. (2004). A preliminary molecular and morphological phylogeny of the Antarctic Epimeriidae and Iphimediidae (Crustacea, Amphipoda). Molecular Phylogenetics and Evolution 31, 4-15.

MacArthur, R. H. \& Wilson, E. O. (1967). Theory of Island Biogeography. Princeton University Press, Princeton.

Matschiner, M., Hanel, R. \& Salzburger, W. (2011). On the origin and trigger of the notothenioid adaptive radiation. PLoS One 6, el8911.

Matute, D. R. (2010). Reinforcement can overcome gene flow during speciation in Drosophila. Current Biology 20, 2229-2233.

Mayr, E. (1942). Systematics and the Origin of Species. Columbia University Press, New York.

MAYR, E. (1984). Evolution of fish species flocks: a commentary. In Evolution of Fish Species Flocks (eds A. A. Echelle and I. KoRNFIELD), pp. 3-12. University of Maine Press, Orono.

McCartney, M. A., Acevedo, J., Heredia, G., Rico, C., Quenoville, B., Bermingham, E. \& McMillan, W. O. (2003). Genetic mosaic in a marine species flock. Molecular Ecology 12, 2963-2973.

MCClain, C. R. \& Hardy, S. M. (2010). The dynamics of biogeographic ranges in the deep sea. Proceedings of the Royal Society of London, Series B: Biological Sciences 277, 3533-3546.

Meyer, J. R. \& Kassen, R. (2007). The effects of competition and predation on diversification in a model adaptive radiation. Nature 446, 432-435.

Moore, P. G. \& Wong, Y. M. (1995). Orchomene namus (Kroyer) (Amphipoda, Lysianassoidea), a selective scavenger of dead crabs - feeding preferences in the field. Fournal of Experimental Marine Biology and Ecology 192, 35-45.

Naish, T. R., Wilson, G. S., Dunbar, G. B. \& Barrett, P. J. (2008). Constraining the amplitude of Late Oligocene bathymetric changes in western Ross Sea during orbitally-induced oscillations in the East Antarctic Ice Sheet: (2) implications for global sea-level changes. Palaeogeography Palaeoclimatology Palaeoecology 260, 66-76.

Near, T. J., Dornburg, A., Harrington, R. C., Oliveira, C., Pietsch, T. W., Thacker, C. E., Satoh, T. P., Katayama, E., Wainwright, P. C., Eastman, J. T. \& Beaulieu, J. M. (2015). Identification of the notothenioid sister lineage illuminates the biogeographic history of an Antarctic adaptive radiation. $B M C$ Evolutionary Biology 15, 109.

NEE, S. (2001). Inferring speciation rates from phylogenies. Evolution 55, 661-668.

Odum, E. (1968). Energy flow in ecosystems: a historical review. American Zoologist 8, $11-18$.

OнтA, T. (1992). The nearly neutral theory of molecular evolution. Annual Review of Ecology and Systematics 23, 263-286.

Patarnello, T., Marcato, S., Zane, L., Varotto, V. \& Bargelloni, L. (2003). Phylogeography of the Chionodraco genus (Perciformes, Channichthydae) in the Southern Ocean. Molecular Phylogenetics and Evolution 28, 420-429.

Pearse, J. S. \& Lockhart, S. J. (2004). Reproduction in cold water: paradigm changes in the 20th century and a role for cidaroid sea urchins. Deep-Sea Research Part II: Topical Studies in Oceanography 51, 1533-1549.

Pearse, J. S., Mooi, R., Lockhart, S. J. \& Brandt, A. (2009). Brooding and species diversity in the Southern Ocean: selection for brooders or speciation within brooding clades? In Smithsonian at the Poles, Contributions to International Polar Year Science (eds I. KrupniK, M. A. Lang and S. E. Miller), pp. 181-196. Smithsonian Institution Press. Washington.

PeCK, L. S. (2002). Ecophysiology of Antarctic marine ectotherms: limits to life. Polar Biology 25, 31-40.

Pisano, E. \& Ozouf-Costaz, C. (1998). Chromosome diversification and the evolution of notothenioid Antarctic fishes. Cytogenetics and Cell Genetics 81, 134-134.

Podos, J., Dyвboe, R. \& Ole Jensen, M. (2013). Ecological speciation in Darwin's finches: parsing the effects of magic traits. Current Zoology 59, 8-19.

Poisot, T., Canard, E., Mouquet, N. \& Hochberg, M. E. (2012). A comparative study of ecological specialization estimators. Methods in Ecology and Evolution 3, $537-544$.

Poulin, E., Palma, A. T. \& Feral, J. P. (2002). Evolutionary versus ecological success in Antarctic benthic invertebrates. Trends in Ecology \& Evolution 17, 218-222. 
Prinzing, A. (2003). Are generalists pressed for time? An interspecific test of the time-limited disperser model. Ecology 84, 1744-1755.

Rabosky, D. L. (2013). Diversity-dependence, ecological speciation, and the role of competition in macroevolution. Annual Review of Ecology, Evolution, and Systematics 44, 481-502. Palo Alto.

Raupach, M. J., Malyutina, M., Brandt, A. \& Waegele, J.-W. (2007). Molecular data reveal a highly diverse species flock within the munnopsoid deep-sea isopod Betamorpha fusiformis (Barnard, 1920) (Crustacea: Isopoda: Asellota) in the Southern Ocean. Deep-Sea Research Part II: Topical Studies in Oceanography 54, 1820-1830.

Raupach, M. J., Thatje, S., Dambach, J., Rehm, P., Misof, B. \& Leese, F. (2010). Genetic homogeneity and circum-Antarctic distribution of two benthic shrimp species of the Southern Ocean, Chorismus antarcticus and Nematocarcinus lanceopes. Marine Biology 157, 1783-1797.

Ribbink, A. J. (1984). Is the species flock concept tenable? In Evolution of Fish Species Flocks (eds A. A. Echelle and I. Konnfield), pp. 21-25. University of Maine at Orono Press, Orono.

Robinson, B. \& WiLson, D. (1994). Character release and displacement in fishes - a neglected literature. American Naturalist 144, 596-627.

Rutschmann, S., Matschiner, M., Damerau, M., Muschick, M., Lehmann, M. F., Hanel, R. \& Salzburger, W. (2011). Parallel ecological diversification in Antarctic notothenioid fishes as evidence for adaptive radiation. Molecular Ecology 20, $4707-4721$.

SAlzburger, W. (2009). The interaction of sexually and naturally selected traits in the adaptive radiations of cichlid fishes. Molecular Ecology 18, 169-185.

SAlzburger, W. \& Meyer, A. (2004). The species flocks of East African cichlid fishes: recent advances in molecular phylogenetics and population genetics. Naturwissenschaften 91, 277-290.

Salzburger, W., Van Bocxlaer, B. \& Cohen, A. S. (2014). Ecology and evolution of the African Great Lakes and their faunas. Annual Review of Ecology, Evolution, and Systematics 44, 519-545.

Saucède, T., Pierrat, B., Danis, B. \& David, B. (2014). Biogeographic processes in the Southern Ocean. Biogeographic Atlas of the Southern Ocean 456-463. Scientific Committee on Antarctic Research, Cambridge.

Schiaparelli, S., Alvaro, M. C., Kilgallen, N., Scinto, A. \& Loerz, A.-N. (2015). Host-shift speciation in Antarctic symbiotic invertebrates: further evidence from the new amphipod species Lepidepecreella debroyeri from the Ross Sea? Hydrobiologia 761, 143-159.

Schliewen, U. K., Tautz, D. \& Paabo, S. (1994). Sympatric speciation suggested by monophyly of crater lake cichlids. Nature 368, 629-632.

Schluter, D. (2000). The Ecology of Adaptive Radiation. Oxford University Press, Oxford. Seehausen, O. (2004). Hybridization and adaptive radiation. Trends in Ecology $\mathbb{E}^{\circ}$ Evolution 19, 198-207.

Seehausen, O. \& van Alphen, J. M. (1999). Can sympatric speciation by disruptive sexual selection explain rapid evolution of cichlid diversity in Lake Victoria? Ecology Letters 2, 262-271.

Servedio, M. R. \& Noor, M. A. F. (2003). The role of reinforcement in speciation: theory and data. Annual Review of Ecology Evolution and Systematics 34, 339-364.

Servedio, M. R., Van Doorn, G. S., Kopp, M., Frame, A. M. \& Nosil, P. (2011). Magic traits in speciation: 'magic' but not rare? Trends in Ecology \& Evolution 26 , 389-397.

Terai, Y., Seehausen, O., Sasaki, T., Takahashi, K., Mizoiri, S., Sugawara, T., Sato, T., Watanabe, M., Konijnendijk, N., Mrosso, H. D. J., Tachida, H., Imai, H., Shichida, Y. \& OKada, N. (2006). Divergent selection on opsins drives incipient speciation in Lake Victoria cichlids. PLoS Biology 4, 2244-2251.

Thatje, S., Hillenbrand, C. D. \& Larter, R. (2005). On the origin of Antarctic marine benthic community structure. Trends in Ecology \& Evolution 20, 534-540.

Thibert-Plante, X. \& Gavrilets, S. (2013). Evolution of mate choice and the so-called magic traits in ecological speciation. Ecology Letters 16, 1004-1013.

Tomaszkiewicz, M., HauTecoeur, M., Coutanceau, J. P., Bonillo, C., Dettaï, A., Mazzei, F., Ghigliotti, L., Pisano, E., Couloux, A., Сhanet, B., Lecointre, G., Detrich, H. I., Duhamel, G. \& Ozouf-Costaz, G. (2011). Comparative cytogenetic studies of the Nototheniidae (Teleostei: Acanthomorpha) from the Indian (Kerguelen-Heard Plateau) and Atlantic (South Georgia, South Sandwich, Falkland/Malvinas, Bouvet Islands) sectors of the Southern Ocean. In The Kergueleen Plateau: Marine Ecosystem and Fisheries (eds G. Duhamel and D. WELSFORD), pp. 109-121. Société française d'ichtyologie, Paris.

Turner, G. F., Seehausen, O., Knight, M. E., Allender, G. J. \& Robinson, R. L. (2001). How many species of cichlid fishes are there in African lakes? Molecular Ecology 10, 793-806.

Turner, J., Bindschadler, R., Convey, P., Di Prisco, G., Fahrbach, E., Gutt, J., Hodgson, D., Mayewski, P. \& Summerhayes, C. (2009). Antarctic Climate Change and the Environment. SCAR \& Scott Polar Research Institute, Cambridge.

Van de Putte, A. P., Janko, K., Kasparova, E., Maes, G. E., Rock, J., Koubbi, P., Volckaert, F. A. M., Choleva, L., Fraser, K. P. P., Smykla, J., Van Houdt, J. K. J. \& MARShall, C. (2012). Comparative phylogeography of three trematomid fishes reveals contrasting genetic structure patterns in benthic and pelagic species. Marine Genomics 8, 23-34.
Verheye, M. L., Backeljau, T. \& d'Udekem d'Accoz, C. (2016). Looking beneath the tip of the iceberg: diversification of the genus Epimeria on the Antarctic shelf (Crustacea, Amphipoda). Polar Biology 39, 925-945.

Volckaert, F. A., Rock, J. \& Van de Putte, A. P. (2012). Connectivity and molecular ecology of Antarctic fishes. In Adaptation and Evolution in Marine Environments (Volume 1, eds G. Di Prisco and C. VERdE), pp. 75-96. (BErlin and HEidelberg): Springer-Verlag Berlin Heidelberg.

Von Rintelen, T. \& Glaubrecht, M. (2005). Anatomy of an adaptive radiation: a unique reproductive strategy in the endemic freshwater gastropod Tylomelania (Cerithioidea : Pachychilidae) on Sulawesi, Indonesia and its biogeographical implications. Biological Journal of the Linnean Society 85, 513-542.

VRBA, E. S. (1987). Ecology in relation to speciation rates: some case histories of Miocene-recent mammal clades. Evolutionary Ecology 1, 283-300.

WAGELE, J. W. (1986). Polymorphism and distribution of Ceratoserolis trilobitoides (Eights, 1833) (Crustacea, Isopoda) in the Weddell Sea and synonymy with Ceratoserolis cormuta (Studer, 1879). Polar Biology 6, 127-137.

Wagner, C. E., Harmon, L. J. \& Seehausen, O. (2012). Ecological opportunity and sexual selection together predict adaptive radiation. Nature 487, 366-U124.

Weber, A. A.-T., Merigot, B., Valiere, S. \& Chenuil, A. (2015). Influence of the larval phase on connectivity: strong differences in the genetic structure of brooders and broadcasters in the Ophioderma longicauda species complex. Molecular Ecology 24, 6080-6094.

Weissing, F. J., Edelaar, P. \& van Doorn, G. S. (2011). Adaptive speciation theory: a conceptual review. Behavioral Ecology and Sociobiology 65, 461-480.

White, M. G. (1998). Development, dispersal and recruitment: a paradox for survival among Antarctic fish. In Fishes of Antarctica. A Biological Overview (eds G. DI PRISCO, E. PisAno and A. Clarke), pp. 53-62. Springer Verlag: Mainland.

Wilson, N. G., Maschek, J. A. \& Baker, B. J. (2013). A species flock driven by predation? Secondary metabolites support diversification of slugs in Antarctica. PLoS One 8(11), e80277.

Wilson, N. G., Schroedl, M. \& Halanych, K. M. (2009). Ocean barriers and glaciation: evidence for explosive radiation of mitochondrial lineages in the Antarctic sea slug Doris kerguelenensis (Mollusca, Nudibranchia). Molecular Ecology 18, 965-984.

Yoder, J. B., Clancey, E., Des Roches, S., Eastman, J. M., Gentry, L., Godsoe, W., Hagey, T. J., Jochimsen, D., Oswald, B. P., Robertson, J., Sarver, B. A. J., Schenk, J. J., Spear, S. F. \& Harmon, L. J. (2010). Ecological opportunity and the origin of adaptive radiations. Fournal of Evolutionary Biology 23, 1581-1596.

Zachos, J., Pagani, M., Sloan, L., Thomas, E. \& Billups, K. (2001). Trends, rhythms, and aberrations in global climate $65 \mathrm{Ma}$ to present. Science 292, 686-693.

\section{APPENDIX GONGEPT DEFINITIONS}

Assortative mating: mating system where reproduction occurs preferentially between similar phenotypes or genotypes for a given trait.

Ecological differentiation: occurs when, among the individuals (considered as genotypes) present in the population, there is variation in the value of a trait, and the individuals displaying intermediate trait values are selectively inferior, so that there is disruptive selection. It could lead to but should not be synonymized with the 'ecological diversity' (ED) criterion as used herein, which refers to a pattern of niche differentiation among species of a flock.

Geographic barrier: a physical barrier separating groups of individuals (populations or metapopulations) that can no longer interbreed because the barrier prevents effective migration.

Hybridization: in the biological species concept, species are delimited by their reproductive isolation. However, there are degrees of reproductive isolation. Some species can hybridize but produce sterile zygotes, so their genomes remain evolutionarily isolated. Others can hybridize and produce individuals with reduced fertility (and/or survival). Seehausen (2004) argued that the possibility of hybridization may favour adaptive radiations. 
Postzygotic barrier: some groups of individuals (can be distinct species), when they interbreed, produce fewer offspring (or fewer fertile offspring) than crosses within groups. For example, in the case of chromosomal rearrangements, a total postzygotic barrier can be present. After sufficiently long geographic isolation, population divergence leads to postzygotic barriers, either due to subdominance at one locus (mainly in F1 hybrids) or to the breaking of co-adapted gene complexes (Dobzhansky-Muller incompatibility).

Prezygotic (assortative mating) barrier: reproduction is not panmictic, genetic groups tending to reproduce with similar genotypes (e.g. via mate choice or incompatibility of gamete surface proteins).

Reinforcement: strengthening of prezygotic reproductive isolation by natural selection in response to postzygotic isolation (Butlin, 1987; Matute, 2010). When offspring among distinct genetic groups have a lower selective value, a character leading to avoidance of reproduction among such groups may increase in frequency due to natural selection. This can be assortative mating or ecological niche differentiation.

(Received 10 February 2017; revised 20 June 2017; accepted 27 June 2017 ) 